\title{
52. STRATIGRAPHIC, VERTICAL SUBSIDENCE, AND PALEOLATITUDE HISTORIES OF LEG 144 GUYOTS ${ }^{1}$
}

\author{
Roger L. Larson, ${ }^{2}$ Elisabetta Erba, ${ }^{3}$ Masao Nakanishi, ${ }^{4}$ Douglas D. Bergersen, ${ }^{5}$ and Jonathan M. Lincoln ${ }^{6}$
}

\begin{abstract}
We summarize the ages and thicknesses of the volcanics and shallow-water carbonate platform sequences recovered by drilling atop guyots on Leg 144, along with results of material previously dredged or drilled in the same areas. To model the subsidence histories of the guyots, we estimate the thermal reset ages of the lithosphere and amounts of initial emergence of the volcanos above sea level as follows: Site 871 (Limalok), $8 \mathrm{Ma}$ thermal reset age of the lithosphere and $171 \mathrm{~m}$ of initial emergence of the volcano above sea level; Site 872 (Lo-En), unknown; Sites 873-877 (Wodejebato), 21 Ma and $236 \mathrm{~m}$; Site 878 (MIT), 19 Ma and $0 \mathrm{~m}$; Sites $879-880$ (Takuyo-Daisan), $22 \mathrm{Ma}$ and $138 \mathrm{~m}$. We then compare observed subsidence of the guyots, as measured by the ages and thicknesses of their carbonate platform sediments, to the Parsons and Sclater (1977) model subsidence curve for oceanic crust formed by seafloor spreading. Limalok, Wodejebato, and Takuyo-Daisan guyots all subsided more slowly than oceanic lithosphere formed by seafloor spreading of the same thermal age. This suggests that the Cretaceous lithosphere cooled more slowly beneath these guyots than in a ridge crest subsidence model, and/or that some dynamic uplift was contributed from the mantle below. By contrast, MIT Guyot subsided in agreement with the Parsons and Sclater (1977) model, suggesting a more normal underlying thermodynamic structure.

The lithosphere beneath Limalok, Wodejebato, and MIT guyots lost significant amounts of thermal age (17-83 Ma) during volcanic construction of these guyots, while the lithosphere beneath Takuyo-Daisan Guyot was essentially unaffected ( 2 Ma age loss). The small thermal age loss to the lithosphere beneath Takuyo-Daisan Guyot during volcanic construction seems incompatible with its subsequent subsidence history, which is slower than model ridge crest subsidence of the same thermal age range. The first observation implies that the underlying thermodynamic structure was unaffected during volcanic construction, but the second observation implies subsequently anomalous thermodynamic conditions. Perhaps the volcano formed over lithosphere and mantle that was unaltered by that volcanic event and then drifted over an anomalous upwelling during the subsequent period of subsidence. Although possible, this explanation appears somewhat contrived.

A paleomagnetic polar wander path for the Pacific Plate is used to reconstruct the paleolatitude histories of these guyots and to define the age and paleolatitude ranges of "crisis zones" for each guyot. These crisis zones are defined by the ages and paleolatitudes of the youngest carbonate platform sediments on each guyot and coincide with the times of death of the ecological communities that built the carbonate platforms. These data all can be encompassed either within a crisis paleolatitude range of $0^{\circ}-10^{\circ} \mathrm{S}$, suggesting a paleoequatorial cause for the death of some of the carbonate platforms, or within a crisis age range of 100-110 Ma, suggesting a cause of death of some of the carbonate platforms related to Albian, and probably late Albian, time. MIT and Takuyo-Daisan guyots fall within both crisis ranges, making the cause of their demise indeterminate by this technique.

The late Albian demise of shallow-water carbonate platforms in the Pacific Ocean and several similar structures in other oceans suggests a global crisis during that time. Widespread hiatuses and/or changes in pelagic sequences and modifications in calcareous planktonic communities support the interpretation of a time-dependent paleoceanographic event, such as modification of water masses, thermocline structure, nutrient availability, and/or global cooling.

The latitude crisis zone coincides with the paleoequatorial upwelling belt of high productivity. We suggest that when the atolls entered this zone of higher nutrient availability, the algal-symbiont-bearing organisms of the carbonate platform community reduced their growth rate because of a decrease in water transparency. Also, as a result of increased availability of nutrients, the population of bio-eroders overwhelmed carbonate-producing organisms, and carbonate accumulation decreased. The final drowning of the guyots may have resulted from a combination of decelerated carbonate production, guyot subsidence, and possibly eustatic sea level rise. This model may explain the atoll-guyot pairs in the Marshall Islands; the differential paleolatitude of the atoll and the guyot with respect to the crisis zone caused the death of the guyot and allowed the atoll to survive.
\end{abstract}

\section{INTRODUCTION}

Hess (1946) discovered about 160 flat-topped seamounts in the Pacific Basin between the Hawaiian and Marianas Islands and named them "guyots" after the geographer Arnold Guyot. He thought that

\footnotetext{
' Haggerty, J.A., Premoli Silva, I., Rack, F., and McNutt, M.K. (Eds.), 1995. Proc. ODP, Sci. Results, 144: College Station, TX (Ocean Drilling Program).

${ }^{2}$ Graduate School of Oceanography, University of Rhode Island, Narragansett, RI 02882-1197, U.S.A.

${ }^{3}$ Dipartimento di Scienze della Terra, Università di Milano, Via L. Mangiagalli 34, I-20133 Milano, Italy.

${ }^{4}$ Ocean Research Institute, University of Tokyo, 1-15-1 Minamidai, Nakano, Tokyo 164, Japan. (Present address: Geological Research Division, Scripps Institution of Oceanography, University of California, San Diego, La Jolla, CA 92093-0212, U.S.A.)

${ }_{5}^{5}$ Department of Geology, University of Sydney, New South Wales 2006, Australia.

${ }^{6}$ Department of Earth and Environmental Studies, Montclair State University, Upper Montclair, NJ 07043, U.S.A
}

they were erosionally truncated, sunken volcanos without coral caps because their typical, summit profile is a flat shelf and not the shape of a modern atoll, dished in the middle with raised outer rims. Hess's conclusion that atolls are not modern analogs of guyots was correct. The guyots drilled on Ocean Drilling Program (ODP) Legs 143 and 144 mainly proved not to be sunken atolls with barrier reefs, but drowned carbonate platforms formed in shallow water (Premoli Silva, Haggerty, Rack, et al., 1993; Sager, Winterer, Firth, et al., 1993). However, although Hess (1946) did not suppose so, guyots are a logical extension of the hypothesis of Darwin (1837), who concluded that atolls, like the carbonate platforms of Legs 143 and 144, form by the subsidence of former volcanos and the subsequent growth of fringing reef systems or carbonate platforms. The Mid-Pac Expedition of 1950 (Hamilton, 1956) first dredged Cretaceous rudists and other shallow-water fossils from flat-topped seamounts in the MidPacific Mountains and thus demonstrated that these guyots had been islands or shallow-water platforms during the Cretaceous. Many more 
guyots have been mapped by echo sounding (e.g., Menard, 1964) and dredged (e.g., Schlanger et al., 1981), but few additional insights have been gained because the in-situ carbonate platforms had not been sampled in stratigraphic order until ODP Legs 143 and 144.

We use the stratigraphic sequences recovered from Leg 144 guyots (see site map preceding title page) to study the vertical subsidence and paleolatitude histories of these guyots during formation of the shallowwater carbonate platforms. The vertical subsidence studies estimate the thermal reset ages of the lithosphere beneath the volcanos and the amounts of emergence of the volcanos above sea level at the end of volcanic activity, and they suggest insights into thermodynamic conditions within the underlying mantle soon after the volcanic formation of the guyots. The paleolatitude histories lend insights into the response of these Cretaceous-Paleogene carbonate systems to changing environmental conditions resulting from changing paleolatitudes; they thus hint at the origins of guyots as sunken islands, formerly maintained at sea level by actively growing carbonate platforms that died for unknown reasons.

Both of these analyses depend heavily on precise and accurate stratigraphies of the carbonate platform sediments. The materials recovered on Leg 144 are not ideal for these purposes. First, because sediment recovery in these sequences was generally less than $10 \%$. Second, because many of the shallow-water fossils are long-ranging and poorly calibrated to other biostratigraphic sequences and thus preclude precise ages with which to calibrate in detail the vertical and horizontal tectonic movements. With these limitations in mind, we present an integrated stratigraphy of the carbonate platform of each guyot. We use that stratigraphy to calculate the subsidence of each guyot and compare that result to subsidence of oceanic lithosphere of the same thermal age formed at a spreading ridge. We use the carbonate platform stratigraphy in conjunction with paleolatitude information derived from other seamount magnetization and magnetic lineation studies on the Pacific Plate to propose a paleolatitude history of each guyot during its carbonate platform sedimentation. This latter study locates places in space and time that seem to encompass the demise of these carbonate platforms. Finally, we speculate on the physical causes of the demise of these ecological systems.

\section{SUBSIDENCE AND PALEOLATITUDE METHODS}

\section{Subsidence Methods and Thermal Reset Ages}

The vertical subsidence that occurred while a carbonate platform was growing can be estimated by simply making a plot of the thicknesses of the carbonate platform sediments as a function of their ages in inverse depositional order. Such a plot is a good approximation of the vertical subsidence history if the following assumptions are correct.

1. The carbonate platform sediments all accumulated essentially at sea level.

2. No compaction of the carbonate platform sediments has occurred.

3. No erosional truncation of the carbonate platform's depositional surface has occurred.

Selective dissolution of a "Swiss cheese" nature could still have happened within the platform carbonate section, but not to the extent that the primary depositional surface was lowered. Violation of any of these assumptions will introduce comparable vertical errors into the following analysis.

The measured rates of subsidence of guyots are of intrinsic ecological interest because they are equivalent to the growth rates of the biological communities that formed the carbonate platforms. These actual growth rates were about an order of magnitude slower than the maximum growth rate capabilities of modern (Grigg and Epp, 1989), and probably the Cretaceous-Paleogene carbonate systems. These rates take on tectonic significance if they are compared to the subsidence rates of normal oceanic lithosphere formed at spreading ridges. This will allow a comparison between the thermodynamic conditions in the asthenosphere beneath normal oceanic lithosphere and beneath the guyots soon after their formation. Any differences between the subsidence histories of these guyots and normal oceanic lithosphere then can be attributed to anomalous thermodynamic conditions in the paleo-asthenosphere beneath the guyots. For such a comparison to be valid, we must compare subsiding lithosphere of the same thermal age in both tectonic environments. This requires that we calculate the "thermal reset age" of the lithosphere beneath each guyot when it formed and that we choose a standard subsidence curve for normal oceanic lithosphere to use in the comparison.

When volcanism occurs in the interior of an otherwise rigid plate, that volcanism interrupts normal thermal subsidence of the lithosphere with uplift because of reheating and perhaps upward-directed forces. These are caused by excess thermal energy and perhaps convective upwelling in the underlying mantle. The plate then begins renewed subsidence in accord with its new thermal and perhaps dynamic structure. This renewed subsidence was recorded by the carbonate platform sediments atop the guyots whose volcanic pedestals were constructed by the Cretaceous volcanic episode within the Pacific Plate. The ages and thicknesses of these platform sediments can be used to construct the early resubsidence history of the region. This measured subsidence can be compared with subsidence models based on particular thermal evolutions to place boundary conditions on the new thermal structure.

The guyots sampled on Leg 144 are shown on the site map preceding the title page. Figure 1 shows the three observations from drilling and seismic profiling that will allow calculation of the preliminary "thermal reset age" of the lithosphere beneath a guyot. A thermal reset age is not an age determined by paleontology or radiometric dating. When a seamount destined to become a guyot is first formed by volcanic activity, the underlying lithosphere usually is uplifted by reheating during that thermal event. The uplifted depth of the lithosphere after the thermal event can be associated with an age on a model subsidence curve. This age is termed the "thermal reset age" (Fig. 2) and generally is younger than the magnetic lineation age of the lithosphere. The two model curves on Figure 3 are different predictions of subsidence as a function of thermal age for normal oceanic lithosphere formed by seafloor spreading at mid-ocean ridges. They are end members of a number of similar subsidence model predictions. The main difference between the two models occurs at ages older than 80 Ma when the Parsons and Sclater (1977) curve predicts significantly more subsidence than the Stein and Stein (1992) curve.

There are two independent methods for calculating preliminary thermal reset ages (Fig. 2). The "guyot height method" simply matches the height of the oldest marine sediment atop the guyot above the oceanic lithosphere of the adjacent deep seafloor (Fig. 1) to that same depth on a model subsidence curve. The age associated with that depth on the model subsidence curve is equivalent to the thermal reset age of the lithosphere when marine sedimentation began as the volcano subsided below sea level. This method requires that the average depth of the adjacent oceanic lithosphere be estimated from regional, seismic reflection surveys, which often is poorly constrained in these remote areas. The depth of the oldest marine sediment on the guyot generally is more tightly constrained by seismic reflection surveys atop the guyot, and by drill-string length at the drill site. The "backtrack method" is a bit more involved. Here, we combine the age of the oldest marine sediment (determined paleontologically) with the depth of this sediment below sea level (determined by the drill-string length) to define a rectangular, age/depth "window" (Fig. 2). That window is matched to the model subsidence curve so that its lower right-hand and upper left-hand corners match two points on the model subsidence curve. The lower right-hand corner is equivalent to the present-day thermal age and depth of the underlying lithosphere, and the upper left-hand corner is equivalent to the thermal reset age and depth when the volcano subsided below sea level.

We utilize both thermal reset age methods and both model subsidence curves to make four different, preliminary estimates of the 


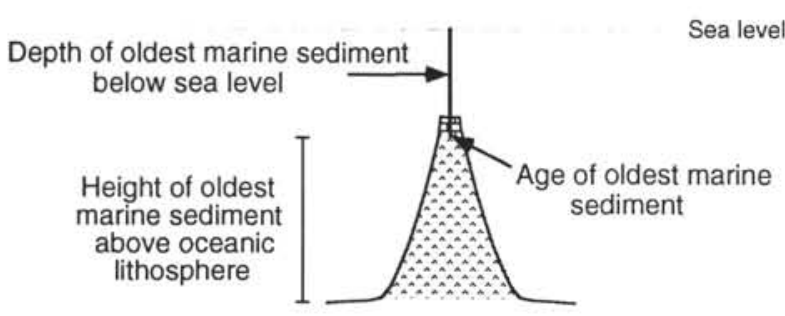

Figure 1. Observations from drilling and seismic profiling used in determining the preliminary estimate of the thermal reset age of the lithosphere beneath a guyot at the onset of marine sedimentation atop the guyot. Depth of the oldest marine sediment atop the guyot was determined by drill-string length; age of the oldest marine sediment was determined by the biostratigraphy of its fossils; and height of the oldest marine sediment atop the guyot above oceanic lithosphere was determined by seismic reflection profiling adjacent to the guyot.

thermal reset age for each guyot. Comparison of these results hopefully will reveal by consistency the preferred method and model subsidence curve. The results are summarized in Table 1. The Parsons and Sclater (1977) subsidence curve clearly gives the most consistent thermal reset ages for both methods. These consistent results are supported by the observation that the present-day, total depth of isostatically corrected oceanic lithosphere near four of the five guyots is now $5900-6100 \mathrm{~m}$ below sea level. This is $\geq 300 \mathrm{~m}$ deeper than any point on the Stein and Stein (1992) curve. Limalok Guyot is the exception, but the surrounding "basement" is probably the top of flood basalts of mid-Cretaceous age and not the top of original Jurassic lithosphere indicated by the adjacent magnetic lineations (Tables 1 and 2). Thus, the Parsons and Sclater (1977) curve is clearly the preferred model for our subsidence calculations, both for the internal consistency of its thermal reset ages, and for its absolute depth predictions. This does not imply that the Parsons and Sclater (1977) model is better than the Stein and Stein (1992) model on a worldwide basis, but simply that it is a better model to use for at least four of the five Leg 144 guyots. Thus, we use a simple average of these two results from the Parsons and Sclater (1977) model for each guyot to establish the preliminary thermal reset ages used as the starting points in our model subsidence calculations.

We can draw our first geological conclusion from this exercise by noting that the age $(114 \mathrm{Ma})$ and depth $(1226 \mathrm{~m})$ of the guyot volcanics on Lo-En Guyot do not permit a thermal reset age to be estimated by the Parsons and Sclater (1977) backtrack method. (We have resorted to the age and depth of the volcanics here because no carbonate platform sediment was recovered. However, the depth of these volcanics must be deeper than any now-eroded platform carbonates and probably about the same age.) The age-depth window that would define such a thermal reset age by the backtrack method extends well beyond $155 \mathrm{Ma}$ on the Parsons and Sclater (1977) curve. If this were true, then the present-day thermal age of lithosphere (the age of the youngest guyot volcanics plus the corrected thermal reset age) beneath Lo-En considerably exceeds $155 \mathrm{Ma}$, and probably also exceeds the magnetic lineation age of the underlying lithosphere (Table 2 ), which is impossible. Mid-plate volcanism reset the thermal age of the lithosphere beneath the other four Leg 144 guyots to ages ranging from 8 to $21 \mathrm{Ma}$ (Table 2), so the present-day thermal age of Lo-En should not be much greater than $135 \mathrm{Ma}(114+21=135)$, at most. This suggests that an assumption has been violated for this calculation, most likely that subsequent uplift took place on Lo-En sometime after its 114-Ma-old volcanics were emplaced. Such subsequent reactivation of Lo-En was suggested by Lincoln et al. (1993). Watkins et al. (this volume) document a pelagic sediment matrix of Campanian age within a volcaniclastic conglomerate from Site 872 atop Lo-En, suggesting Campanian tectonic reactivation and some associated volcanism, coeval with volcanism on nearby Wodejebato Guyot.

Figure 4 shows the model subsidence curves for each guyot using the Parsons and Sclater (1977) and Stein and Stein (1992) model

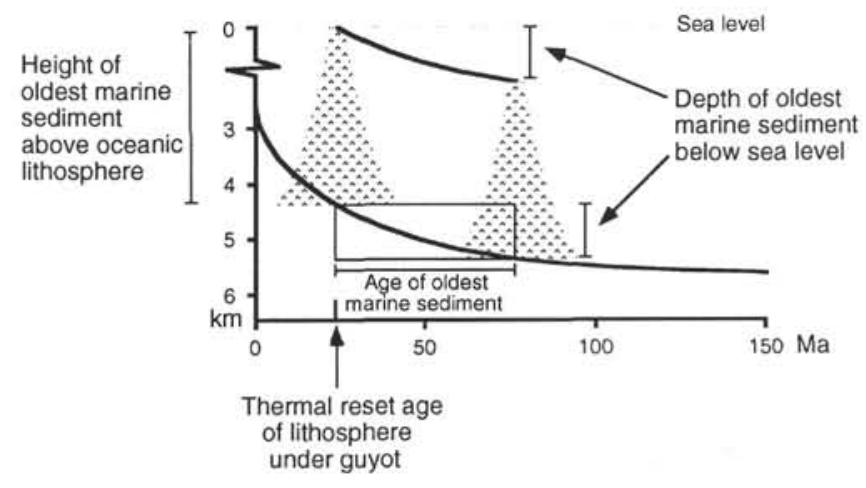

Figure 2. Preliminary determination of thermal reset age of oceanic lithosphere under a guyot at the onset of marine sedimentation utilizes the height above oceanic lithosphere of the oldest marine sediments on the guyot in the "guyot height method" and a combination of the depth of these marine sediments below sea level and the age these marine sediments in the "backtrack method" (Table 1). These methods assume that marine sedimentation began when the top of the volcano had subsided to sea level, and thus they use sea level as the "reference datum."

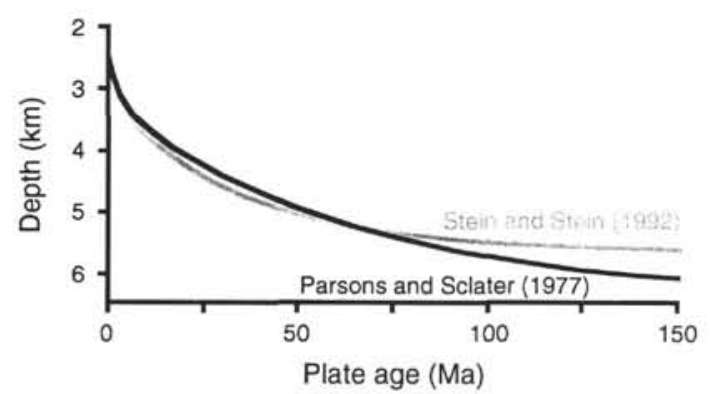

Figure 3. Subsidence curves for normal oceanic lithosphere formed by seafloor spreading at oceanic ridges. Although other intermediate models exist, the Parsons and Sclater (1977) and Stein and Stein (1992) curves are the "end members" for lithosphere older than $80 \mathrm{Ma}$.

subsidence curves from Table 1. Because the thermal reset ages for the Parsons and Sclater (1977) curve are always larger (older) than the ages determined with the Stein and Stein (1992) curve, the Parsons and Sclater (1977) curve always predicts slower initial subsidence rates (Fig. 4). The model subsidence curve can be compared to the subsidence history of the carbonate platform sediments for each guyot except for Lo-En for which no model subsidence curve can be calculated, and where volcanic substrate was encountered directly beneath the pelagic cap. A significant problem with using the oldest marine sediments atop the guyot to determine the thermal reset age is the necessary assumption that the top of the guyot's volcanic sequence began its subsidence history from sea level. This is unlikely to be true for most guyots because volcanic islands in today's oceans often rise several hundred meters or more above sea level during their magmatic formative years. If this assumption is violated, then both the guyot height and backtrack methods will overestimate the thermal reset age, and the model subsidence curve will be displaced downward relative to the actual subsidence data. To recognize this problem, we first look for an age gap (Fig. 5) between the oldest marine sediments and youngest volcanic rocks that might represent the time of emergence above sea level. If this time gap exists, we then can correct the problem by backtracking up the subsidence curve from the preliminary thermal reset age that was approximated using sea level as the starting point, by a time amount equal to the sediment-volcanic age gap. The difference between these two depths on the subsidence curve is an approximation of the maximum amount of emergence of 
Table 1. Preliminary estimates of thermal reset ages of lithosphere under guyots, using ages, depths, and heights of oldest marine sediments.

\begin{tabular}{lrrrrc}
\hline & Limalok & Lo-En & Wodejebato & MIT & Takuyo-Daisan \\
\hline $\begin{array}{l}\text { Oldest guyot sediment data: } \\
\text { Oldest marine sediment age }(\mathrm{Ma})\end{array}$ & 58 & $114^{*}$ & 76 & 121 & 115 \\
Depth below sea level $(\mathrm{m})$ & 1681 & 1226 & 1485 & 2053 & $1815^{* *}$ \\
Height above oceanic lithosphere $(\mathrm{m})$ & 3669 & 4679 & 4420 & 4052 & 4300 \\
Preliminary thermal reset ages: & & & & & \\
S\&S backtrack (Ma) & 7 & 24 & 14 & 6 & $10^{* *}$ \\
S\&S guyot height (Ma) & $8^{\dagger}$ & 34 & 25 & 16 & 22 \\
P\&S backtrack (Ma) & 11 & 11 & 26 & 18 & $25^{* *}$ \\
P\&S guyot height (Ma) & $11^{+}$ & 40 & 31 & 20 & 27 \\
P\&S mean age (Ma) & 11 & $?$ & 29 & 19 & 26 \\
\hline
\end{tabular}

Note $=$ Notes: $\mathrm{S} \& S=$ Stein and Stein (1992); P\&S = Parsons and Sclater $(1977) ; *=$ youngest guyot volcanic age because no shallow-water marine sediment was recovered; ** = assumes $150 \mathrm{~m}$ of outer bulge uplift: $\dagger=$ oceanic "basement" is probably Cretaceous volcanics; $\uparrow \dagger=$ plate age exceeded in calculation.
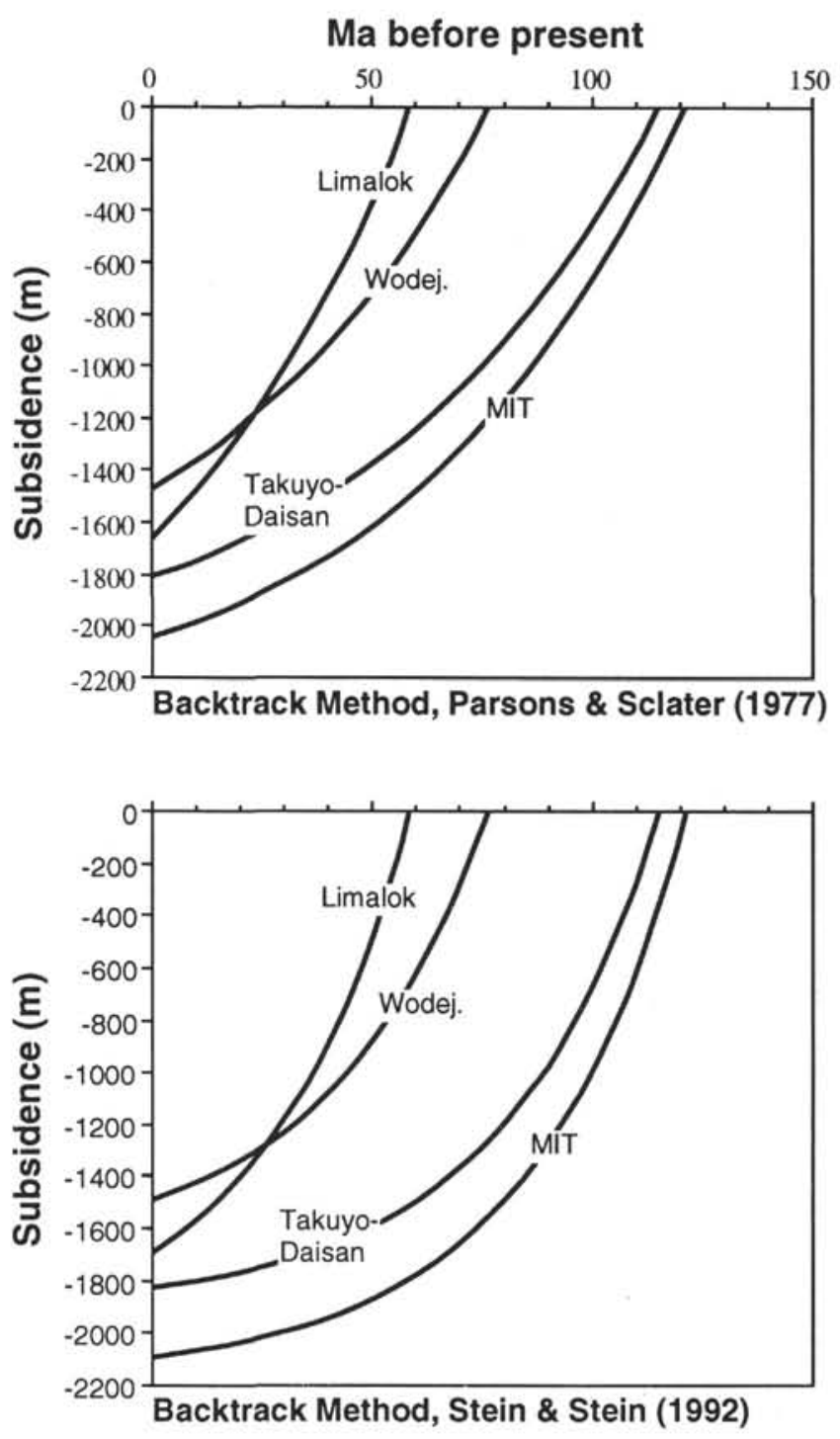

Figure 4. Theoretical subsidence histories since the onset of marine sedimentation of Leg 144 guyots based on the subsidence curves of Parsons and Sclater (1977) and Stein and Stein (1992), and on the thermal reset ages from Table 1. The Parsons and Sclater (1977) model always predicts the slowest initial subsidence because the thermal reset ages are always larger (older) in this model. the volcano above sea level, and it can be factored into an improved thermal reset age calculation by adding it to the depth below sea level of the oldest marine sediments and subtracting it from the guyot height above oceanic lithosphere. This procedure allows the calculation of a more precise thermal reset age, as well as an estimate of the amount of initial emergence of the volcano above sea level (Table 2).

\section{Paleolatitude Methods}

An analysis of the paleolatitude history of each of the Leg 144 guyots during the times of carbonate platform sedimentation may lend insight into the response of the ecological communities of the carbonate platforms to changing paleolatitudes. The only reliable paleolatitude history for the Pacific Plate that extends back to the age of the oldest guyot platform (121 Ma on MIT Guyot) is a polar wander path based on seamount magnetization (Sager and Pringle, 1988) and magnetic anomaly skewness (Larson and Sager, 1992). Plate motion models based on fixed hotspots (e.g., Lancelot and Larson, 1975; Duncan and Hargraves, 1984) only extend back to the age of the oldest Emperor Seamounts (70-80 Ma). These hotspot models were compared to the seamount results of Sager and Pringle (1988) by Larson et al. (1992) and found to be in reasonable agreement, in that paleolatitudes generally match within $5^{\circ}-10^{\circ}$ between models. However, there is no obvious hotspot "trail" still remaining in the Pacific Basin that can be traced continuously before this time. We regard as unreliable attempts to construct motion histories for the Pacific Plate before 70-80 Ma based on fixed hotspot models.

Paleolatitude histories of Leg 144 guyots during their times of carbonate platform sedimentation can be calculated by combining the age history of carbonate platform sedimentation with the paleomagnetic polar wander path of the Pacific Plate for those same ages. The remanent magnetic inclination information obtained from the guyots themselves on Leg 144 (Nakanishi and Gee, this volume; Ito and Nogi, this volume) are used as supportive data in this exercise and are not used in the paleolatitude calculations. This is done primarily because we require a continuous paleolatitude history during the time of carbonate platform sedimentation on each guyot, and the remanent magnetic inclination information cited above from the Leg 144 guyots only gives estimates of the paleolatitudes at the times of their volcanic formation. In addition, accurate paleolatitude histories require derivation from large, averaged data sets, and in particular, neither the carbonate platform sediments nor the underlying volcanics from the guyots are likely to be particularly accurate recorders of magnetic vector directions when those edifices formed. In contrast, the paleomagnetic poles utilized in this calculation are averaged results from numerous seamount pole calculations (Sager and Pringle, 1988) for the Late Cretaceous and from a similarly large data set for magnetic lineations M0 to M4 (Larson and Sager, 1992) for times before the oldest seamount pole at $88 \mathrm{Ma}$. Finally, use of the same paleomagnetic polar wander path for all of the guyots will provide a common basis for comparison of the results.

Paleolatitude histories are calculated for each guyot by calculating the Great Circle distances from the present-day location of the ODP 
Table 2. Correction to thermal reset ages of lithosphere under guyots due to initial emergence of volcanos above sea level, using age differences between oldest marine sediments and youngest guyot volcanics.

\begin{tabular}{|c|c|c|c|c|c|}
\hline & Limalok & Lo-En & Wodejebato & MIT & Takuyo-Daisan \\
\hline $\begin{array}{l}\text { Age corrections: } \\
\text { Youngest guyot volcanic age (Ma) } \\
\triangle \mathrm{Age}^{*}(\mathrm{Ma})\end{array}$ & $\begin{array}{r}61 \\
3\end{array}$ & $\begin{array}{c}114 \\
?\end{array}$ & $\begin{array}{r}83 \\
7\end{array}$ & $\begin{array}{r}121 \\
0\end{array}$ & $\begin{array}{r}119 \\
4\end{array}$ \\
\hline $\begin{array}{l}\text { Corrected thermal reset ages: } \\
\text { P\&S backtrack (Ma) } \\
\text { P\&S guyot height }(\mathrm{Ma}) \\
\text { P\&S mean age }(\mathrm{Ma}) \\
\text { Initial emergence of volcano }(\mathrm{m})\end{array}$ & $\begin{array}{r}7 \\
8 \\
8 \\
171\end{array}$ & $\begin{array}{l}* * \\
? \\
?\end{array}$ & $\begin{array}{r}19 \\
23 \\
21 \\
236\end{array}$ & $\begin{array}{r}18 \\
20 \\
19 \\
0\end{array}$ & $\begin{array}{r}21^{\dagger} \\
23 \\
22 \\
138\end{array}$ \\
\hline $\begin{array}{l}\text { Ages of lithosphere beneath guyots: } \\
\text { Magnetic lineation } \\
\text { Magnetic lineation age } \\
\text { Present-day thermal age }(\mathrm{Ma}) \\
\text { Thermal age loss }(\mathrm{Ma})^{+5}\end{array}$ & $\begin{array}{r}\mathrm{M} 22 \\
152 \\
69 \\
83\end{array}$ & $\begin{array}{c}>\mathrm{M} 29 \\
\sim 160 \\
? \\
?\end{array}$ & $\begin{array}{r}>\mathrm{M} 29 \\
\sim 160 \\
104 \\
\sim 56\end{array}$ & $\begin{array}{r}\mathrm{M} 28 \\
157 \\
140 \\
17\end{array}$ & $\begin{array}{r}\text { M16 } \\
143 \\
141 \\
2\end{array}$ \\
\hline
\end{tabular}

Notes: P\&S = Parsons and Sclater (1977); * = youngest guyot volcanic age minus oldest marine sediment age (from Table 1 ); $* *=$ plate age exceeded in calculation; $\dagger=$ assumes 150 $\mathrm{m}$ of outer bulge uplift; $\uparrow+=$ from Nakanishi et al. $(1992 \mathrm{a}, 1992 \mathrm{~b}) ; \xi=$ using the Harland et al. (1990) time scale; $8 \S=$ mean corrected thermal reset age + youngest guyot volcanic age; $\leftarrow=$ magnetic lineation age - thermal age.

drill site to the present-day locations of the averaged poles (Fig. 6) or to locations along straight-line paths between poles for interpolated ages. The Great Circle connecting a drill site and a paleomagnetic pole location is the angular distance of the drill site from the North Pole for the age of the paleomagnetic pole. This is in accord with the geocentric, axial dipole assumption of paleomagnetism that the paleomagnetic pole location at the time of formation was coincident with the North Pole (the spin axis of Earth). A straight line drawn from the North Pole to the site location must be along a line of longitude, which is a Great Circle path. If the length of this Great Circle path (in degrees) is subtracted from $90^{\circ}$, the result is the paleolatitude of the site.

Paleolatitudes were calculated at 5-m.y. intervals for each of the guyots during the time span of carbonate platform sedimentation on that guyot (Figs. 7-12). These results were plotted with the subsidence information for each guyot. The age and paleolatitude ranges of each calculation reflect the $95 \%$ confidence limits on the age and location of the paleomagnetic pole. If the maximum and minimum extremes of the paleolatitude limits were connected between the 5-m.y. calculation points, the two lines would form a swath representing the limits of the complete paleolatitude history of each guyot.

\section{STRATIGRAPHY OF THE CARBONATE PLATFORMS}

The stratigraphic framework illustrated in the Frontispiece is used as the Leg 144 reference for the Barremian to Maastrichtian interval. It is based on the time scale recently proposed by Gradstein et al. (1994) and includes the calibration of calcareous nannofossil, planktonic and benthic foraminiferal biostratigraphy with magnetostratigraphy. The time scale of Cande and Kent (1992) and Cande and Kent (1995) is used for the Tertiary and Quaternary intervals. While the stratigraphies of the sedimentary sections and the radiometric ages of the volcanic pedestals recovered during Leg 144 are documented in a number of specialty papers, Erba et al. (this volume) present a detailed synthesis of the stratigraphic results of the shallow-water sequences.

In this section, we discuss the age and thickness of the volcanics and subsequent sedimentary sequences that were drilled at Sites 871 through 880 , along with previous results from material dredged and drilled in the same areas and published in the literature. This data set (Figs. 7-12) is used in this and the next section to reconstruct the geological history of the guyots and to estimate their subsidence and paleolatitude histories.

\section{Site 871 (Limalok Guyot)}

Site 871 (Figs. 7 and 8) is located on the summit of Limalok Guyot, near its center. Drilling penetrated into and bottomed in 48.5 $\mathrm{m}$ of interbedded volcanogenic sandstones and basaltic breccias and

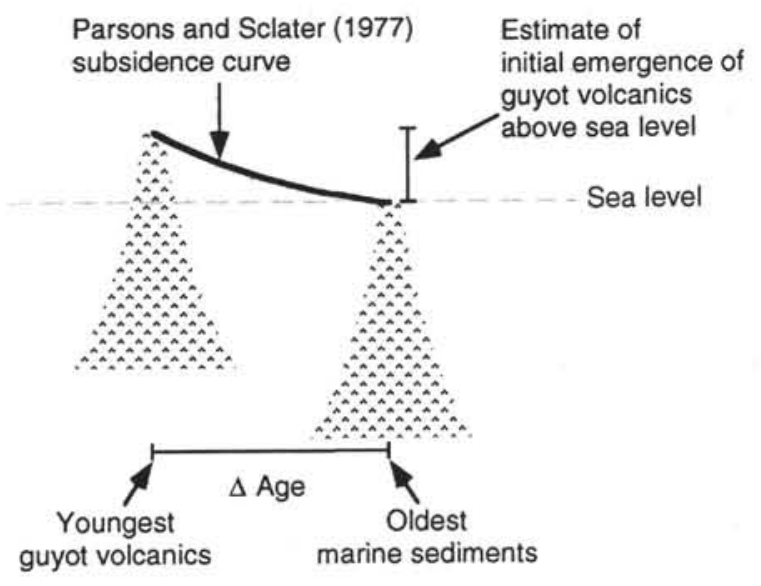

\section{Correction for emergence of guyot volcanics above sea level}

\author{
Backtrack method: \\ Depth of oldest marine sediment below sea level \\ + initial emergence \\ Guyot height method: \\ Height of oldest marine seiment above oceanic lithosphere \\ - initial emergence
}

Figure 5. Correction of the preliminary estimate of the thermal reset age (Table 1) to account for possible initial emergence of the volcano above sea level (Table 2). Any age difference between the oldest marine sediments (determined by biostratigraphy) and the youngest guyot volcanics (determined by radiometric dating) is subtracted from the preliminary thermal reset age estimate. The depth difference between these two ages on the Parsons and Sclater (1977) subsidence curve is then used to estimate a more precise thermal reset age at the end of volcanic activity, and it is also an estimate of the amount of initial emergence above sea level of the original volcano (Table 2).

flows (Unit IV). Material suitable for radiometric dating was not recovered at this site and, therefore, the age of the volcanic pedestal is inferred from the biostratigraphic age of the oldest sediment and rates of subaerial weathering of the volcanics. Volcanics are overlain by $29 \mathrm{~m}$ of variegated clays with common basalt pebbles in the lower part. This interval is considered a subaerial weathering profile over the basalt and attests to a relatively long period of exposure, probably beginning in an upland area at least several tens of meters above sea level (Holmes, this volume). This thick weathering profile required no less than one million years of soil formation and most probably as much as three million years to form (Holmes, this volume). 


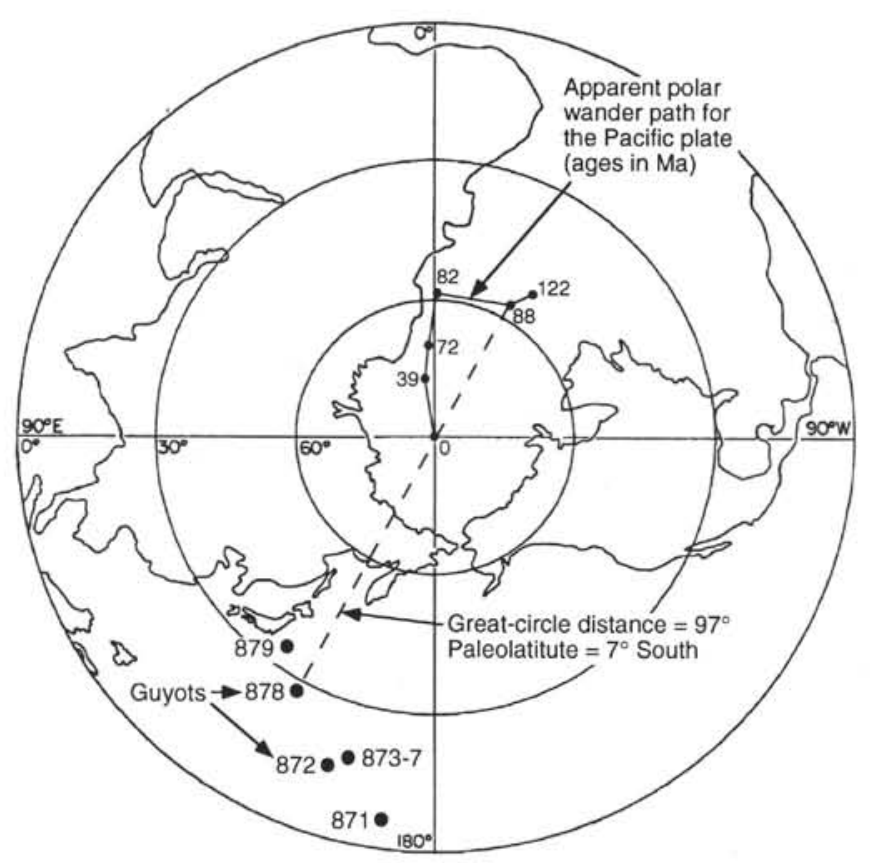

Figure 6. Method used to determine paleolatitude histories of the guyots. Each paleolatitude is determined by measuring the angular Great Circle distance from the present-day guyot location to a point on the Pacific Plate polar wander path determined by Sager and Pringle (1988) and Larson and Sager (1992). When $90^{\circ}$ is subtracted from that Great Circle distance, the remainder is the paleolatitude. Errors in this calculation are the same as the errors in age and location of the paleomagnetic pole position in the polar wander path.

The oldest marine sediment consists of dark gray aragonitic grainstones and clays with depauperate nannofloras of early late Paleocene age (Premoli Silva, Haggerty, Rack et al., 1993; Watkins et al., this volume). The initial stage of inundation of the island occurred under relatively restricted conditions and was followed by a thick sequence $(289.2 \mathrm{~m})$ of shallow-water limestones deposited during the latest Paleocene to middle Eocene interval. Possible hiatuses were identified in the upper Paleocene and middle Eocene, but benthic foraminiferal biostratigraphy does not allow a quantification of the missing intervals (Nicora et al., this volume). The youngest platform carbonates on Limalok Guyot were dated as early middle Eocene (Nicora et al., this volume), and the oldest pelagic sediment was found in the manganese crust atop the shallow-water sequence. Here, a welldiversified nannofossil assemblage indicative of the CP13 Zone suggests that the platform drowned and open marine conditions were established over the guyot by the middle Eocene (Premoli Silva, Haggerty, Rack et al., 1993; Watkins et al., this volume). Pelagic sedimentation during the late Eocene and Oligocene was documented only in the crust of manganese oxide and in bore fillings as reconstructed by Watkins et al. (this volume). Most of the pelagic cap atop Limalok Guyot accumulated in the Neogene and was strongly affected by winnowing and non-deposition. The Miocene and Pliocene accumulation is very discontinuous (Watkins et al., this volume), whereas the Quaternary seems to be complete (Erba, this volume).

\section{Site 872 (Lo-En Guyot)}

Three holes were drilled near the center of Lo-En Guyot (Fig. 9). Holes $872 \mathrm{~A}$ and $872 \mathrm{C}$ recovered the pelagic cap, whereas Hole $872 \mathrm{~B}$ penetrated $57 \mathrm{~m}$ of volcanics. Pringle and Duncan (this volume) provided radiometric ages for two rock samples from the alkalic basalts; the weighted isochron age is $112.8 \pm 1.2 \mathrm{Ma}$. The dating standard ( $85 \mathrm{G} 003$ TCR sanadine at $27.92 \mathrm{Ma}$ ) used by Pringle and Duncan (this volume) for the volcanics from Sites $872-878$ is differ-

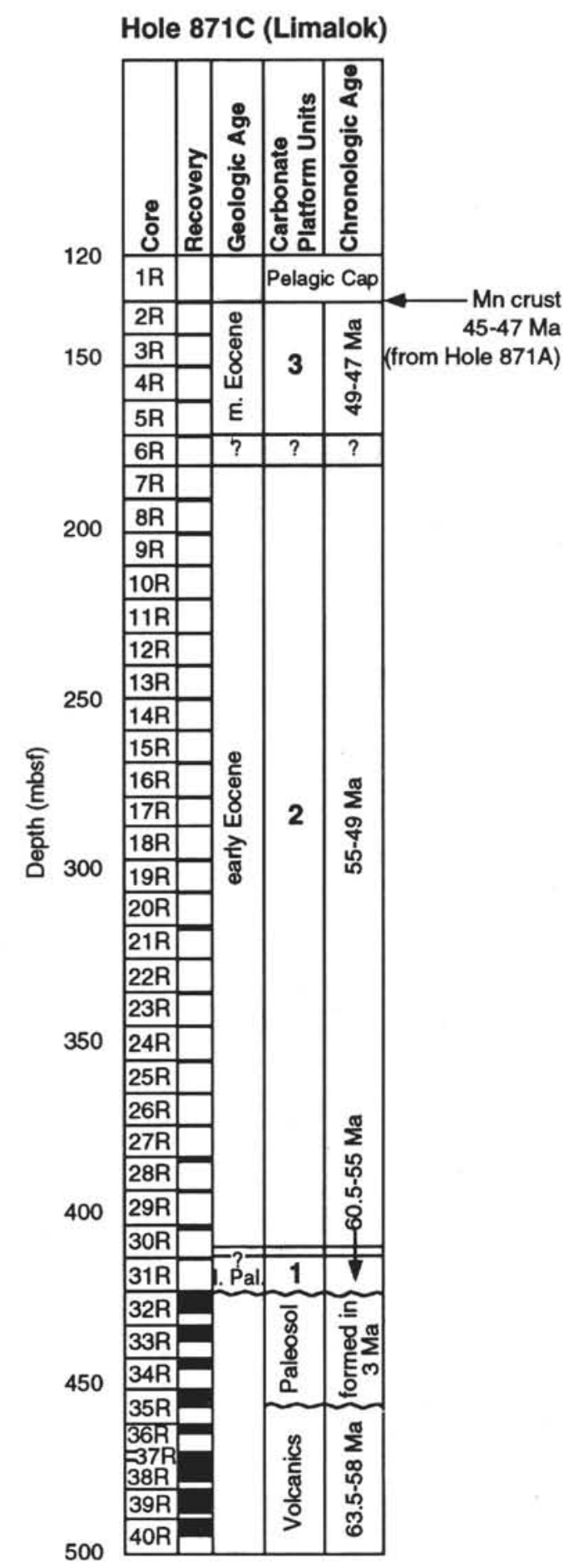

Figure 7. Simplified stratigraphic column for Site 871 (Limalok Guyot), illustrating how the carbonate platform stratigraphy is partitioned into units of particular age and depth ranges (labeled 1,2, and 3 in the "carbonate platform units" column) to construct the observed subsidence history for the guyot. Note that these stratigraphic units are plotted in inverse stratigraphic order on the following subsidence diagrams to illustrate the concordant subsidence and sedimentation histories. 


\section{Stratigraphy, Subsidence and Paleolatitude}
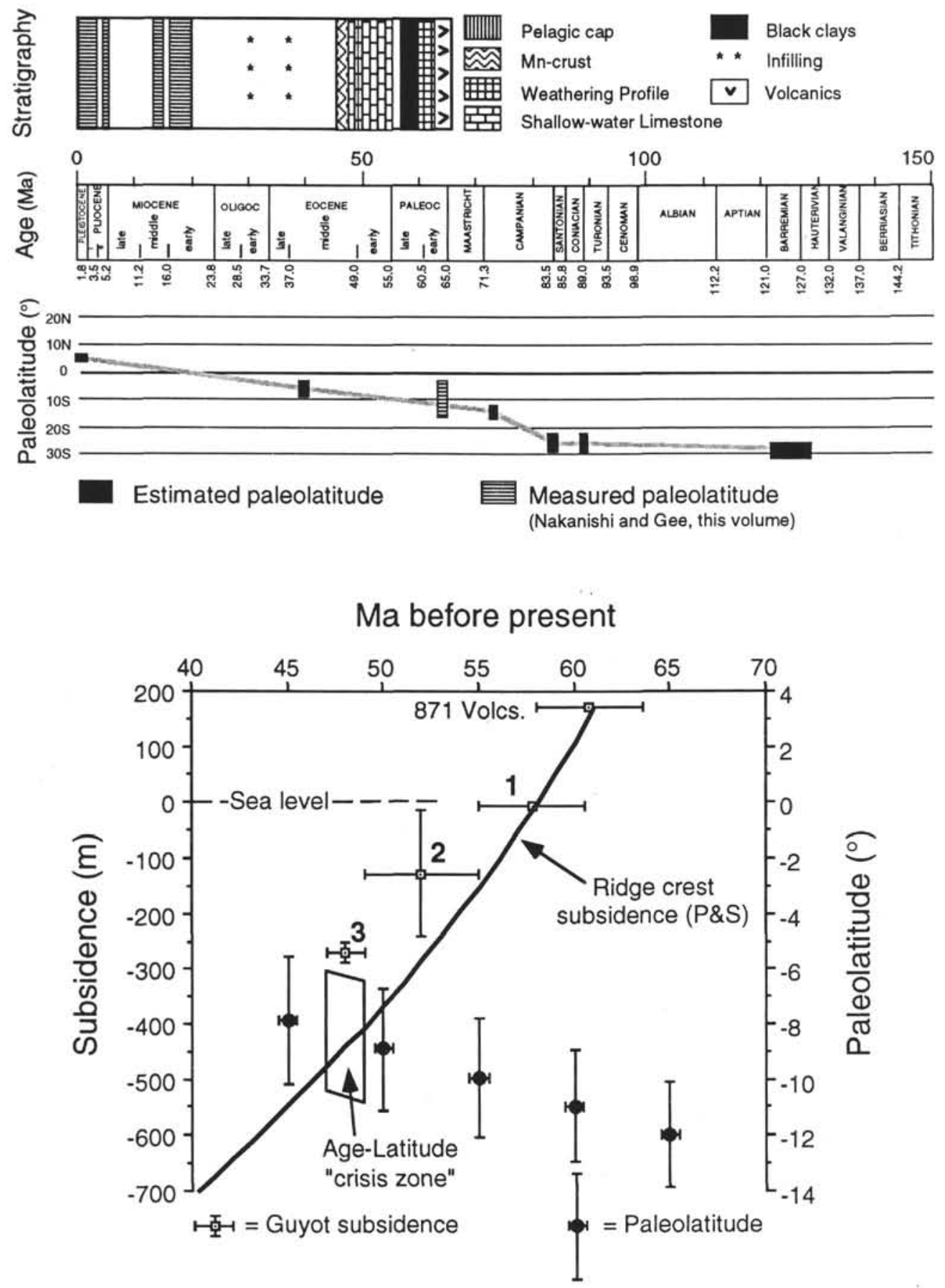

Figure 8. Upper half of diagram shows the complete stratigraphy and estimated paleolatitude histories of Site 871 (Limalok Guyot). Diagrams for other guyots also show dredge information from the guyot, if available and relevant. Black boxes on the estimated paleolatitude plot are bounded by the error limits of the paleomagnetic pole locations and ages on the Pacific Plate polar wander path (Fig. 6). Lined box on the same diagram is bounded by the error limits of paleolatitudes from the measured remanent magnetic inclinations of the volcanics at Site 871 (Nakanishi and Gee, this volume). Open circles on subsequent paleolatitude diagrams are paleolatitude estimates from downhole logging in the volcanics (Ito and Nogi, this volume). Lower half of the diagram is a detailed view of the early subsidence and paleolatitude histories of Site 871 (Limalok Guyot) during carbonate platform sedimentation. "Guyot subsidence" below sea level corresponds with the carbonate platform units labeled 1,2, and 3 in Figure 7 and is plotted here in inverse depositional order. The "Volcs." data point at the top of the subsidence curve is the radiometric age and the estimate of the initial emergence above sea level of the volcano. Thicknesses of drilled volcanics, including subariel weathered claystone units, are not shown. "Ridge crest subsidence (P \& S)" is the theoretical subsidence curve for normal oceanic lithosphere of the same thermal age (Table 2) based on the Parsons and Sclater (1977) model. "Paleolatitude" is a set of age-paleolatitude ranges calculated at a 5-m.y. interpolation interval using the paleomagnetic pole data shown in the upper half of the diagram and in Figure 6. "Age-latitude crisis zone" is the age and paleolatitude ranges of the youngest carbonate platform sediments. 


\section{Stratigraphy, Subsidence and Paleolatitude}
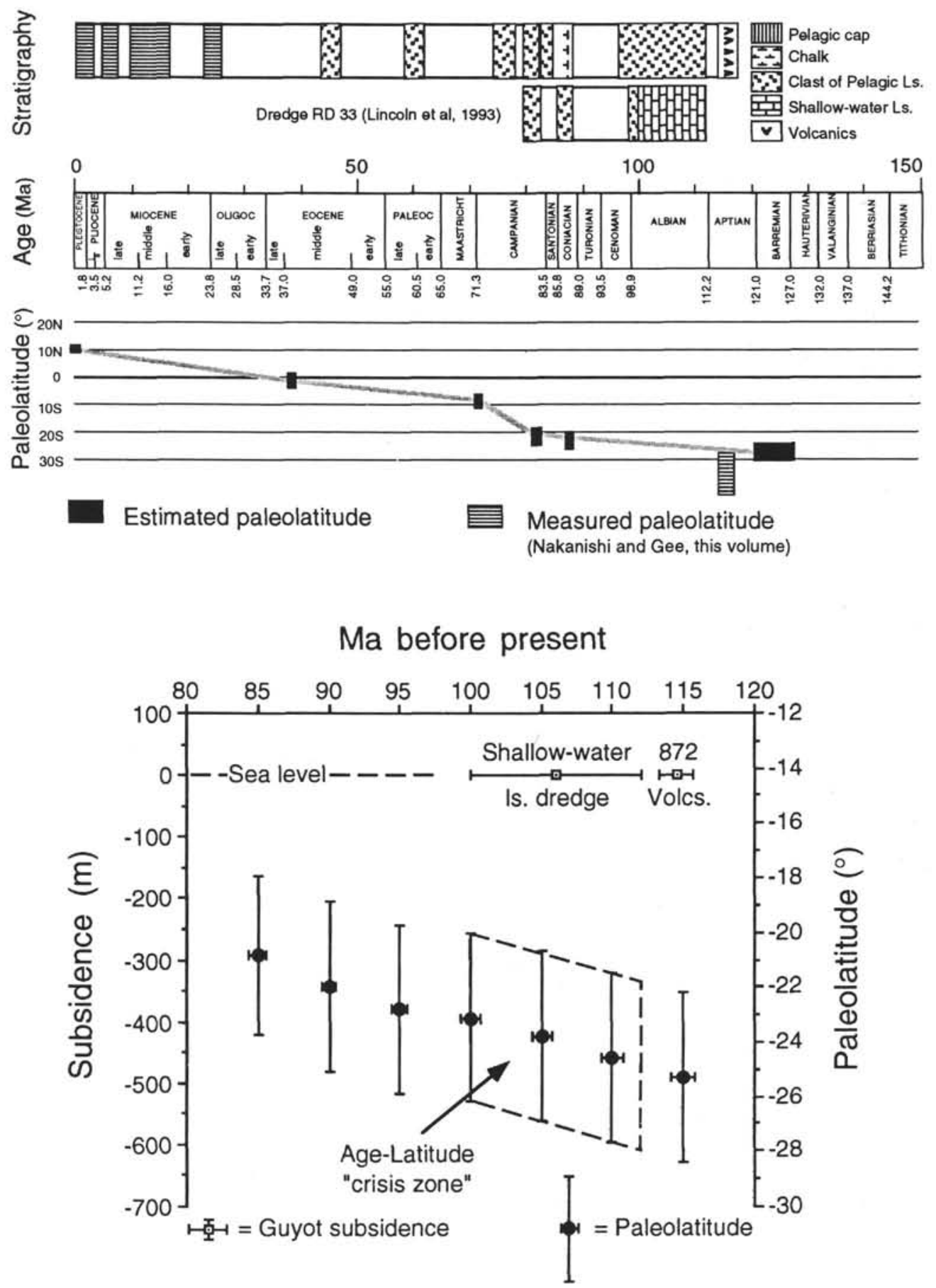

Figure 9. Stratigraphy, subsidence and paleolatitude histories of Site 872 (Lo-En Guyot). See Figure 8 for complete description. In addition, note that the "shallow-water ls. dredge" and "872 Volcs." age ranges are plotted at sea level. Their depths on a subsidence curve cannot be estimated because they were subsequently uplifted by an unknown amount sometime after their initial emplacement (see text).

ent from that used by Obradovich (1993). Therefore, ages provided by Pringle and Duncan (this volume) for those sites cannot be compared directly with the Gradstein et al. (1994) time scale because it is derived from Obradovich (1993) and is used as our reference time scale as shown in the Frontispiece. Applying a multiplication factor of 1.01417 to the ages reported by Pringle and Duncan (this volume) for the volcanics from Sites 872-878, we obtain an age of $114.5 \pm 1.2$
Ma for the volcanics from Hole 872B calibrated to the Gradstein et al. (1994) time scale.

Although Lo-En Guyot is morphologically a classic, flat-topped guyot, drilling did not recover any platform sequence. At Site 872 only a few fragments of black claystones indicate a possible derivation from a relatively fresh to moderately weathered terrain, and the limestones recovered at this site suggest persistent pelagic deposi- 
Stratigraphy, Subsidence and Paleolatitude

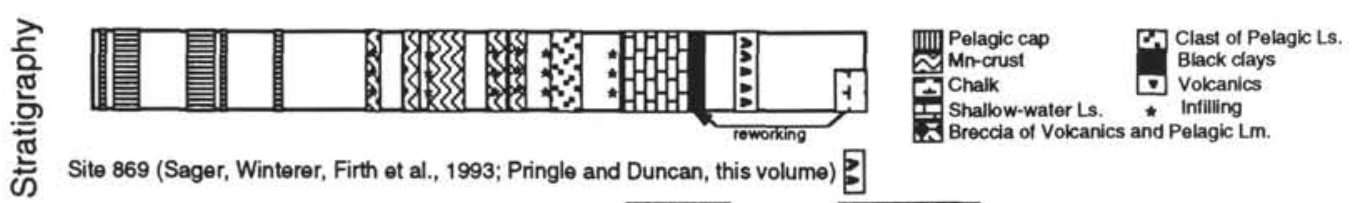

Dredge RD 50 (Lincoln et al., 1993) H.ㅐㅐㅐㅐㅐㅐ

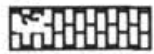

Dredge RD 47 (Lincoln et al., 1993) 28
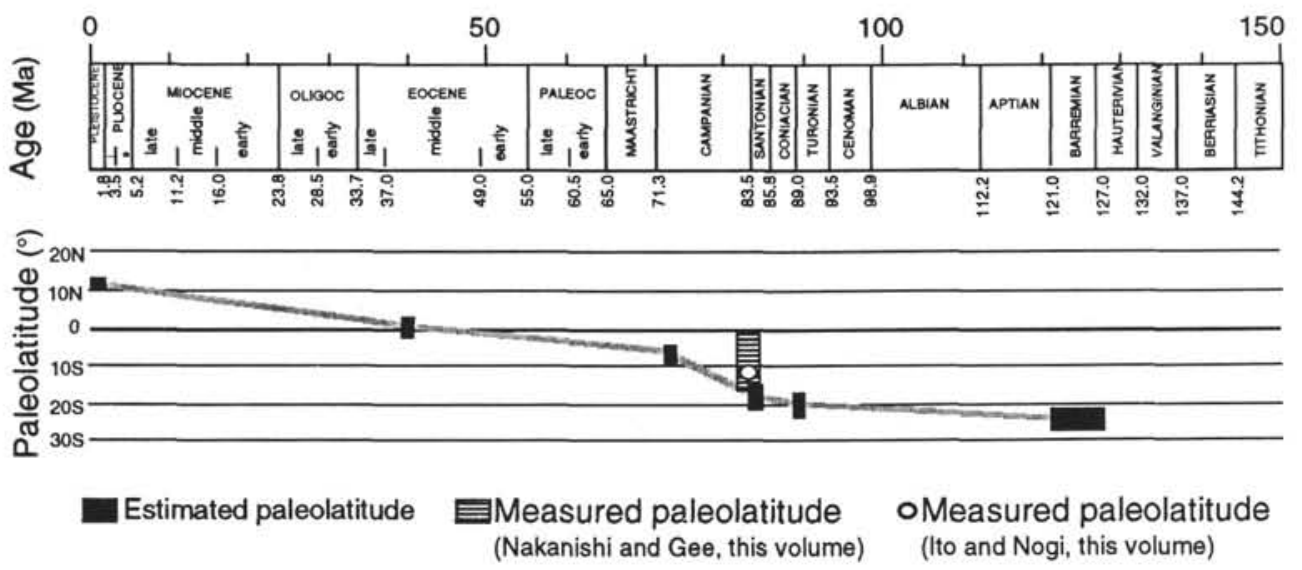

Ma before present

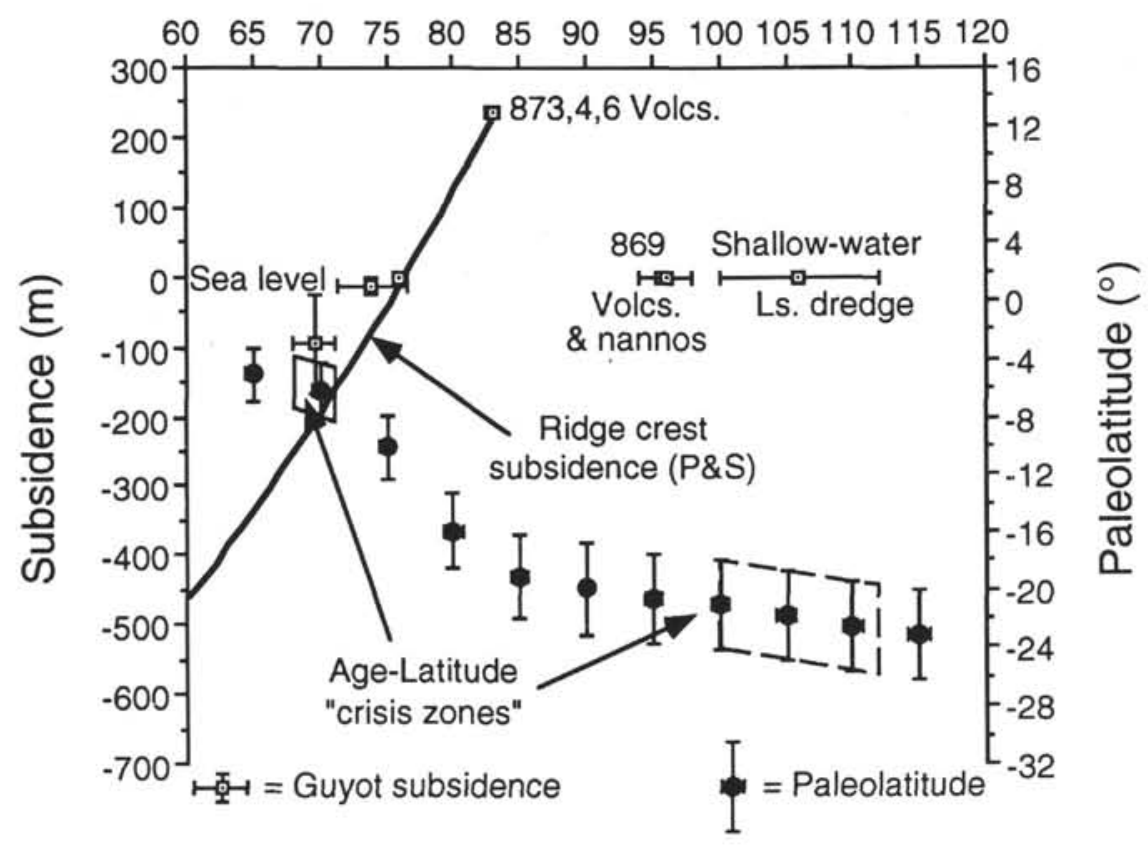

Figure 10. Stratigraphy, subsidence and paleolatitude histories of Sites $873-877$ (Wodejebato Guyot). See Figure 8 for complete description. In addition, note that the "869 Volcs. \& nannos" and "shallow-water ls. dredge" age ranges are plotted at sea level. Their depths on an initial subsidence curve cannot be estimated because they were uplifted to sea level by the subsequent volcanic event at $83 \mathrm{Ma}$.

tion over the volcanic edifice near the center of the guyot. The oldest sediment is a phosphatized clast of pelagic limestone containing a depauperate nannoflora of Albian to earliest Cenomanian age (Watkins et al., this volume). Pelagic sediments also occur as crack fillings and as matrix of the volcaniclastic pebble conglomerate lying atop the basaltic pedestal (Premoli Silva, Haggerty, Rack, et al., 1993; Watkins et al., this volume). The intense phosphatization and small size of samples limit the biostratigraphic resolution; however, planktonic foraminifers and calcareous nannofossils indicate that pelagic sedimentation occurred during the late Coniacian-Santonian, early and middle Campanian, late early Paleocene, and middle Eocene (Watkins et al., this volume). The presence of middle neritic benthic foraminifers in the late Coniacian-Santonian limestones possibly suggests a shallow pelagic environment or transport of shallow-water 


\section{Stratigraphy, Subsidence and Paleolatitude}
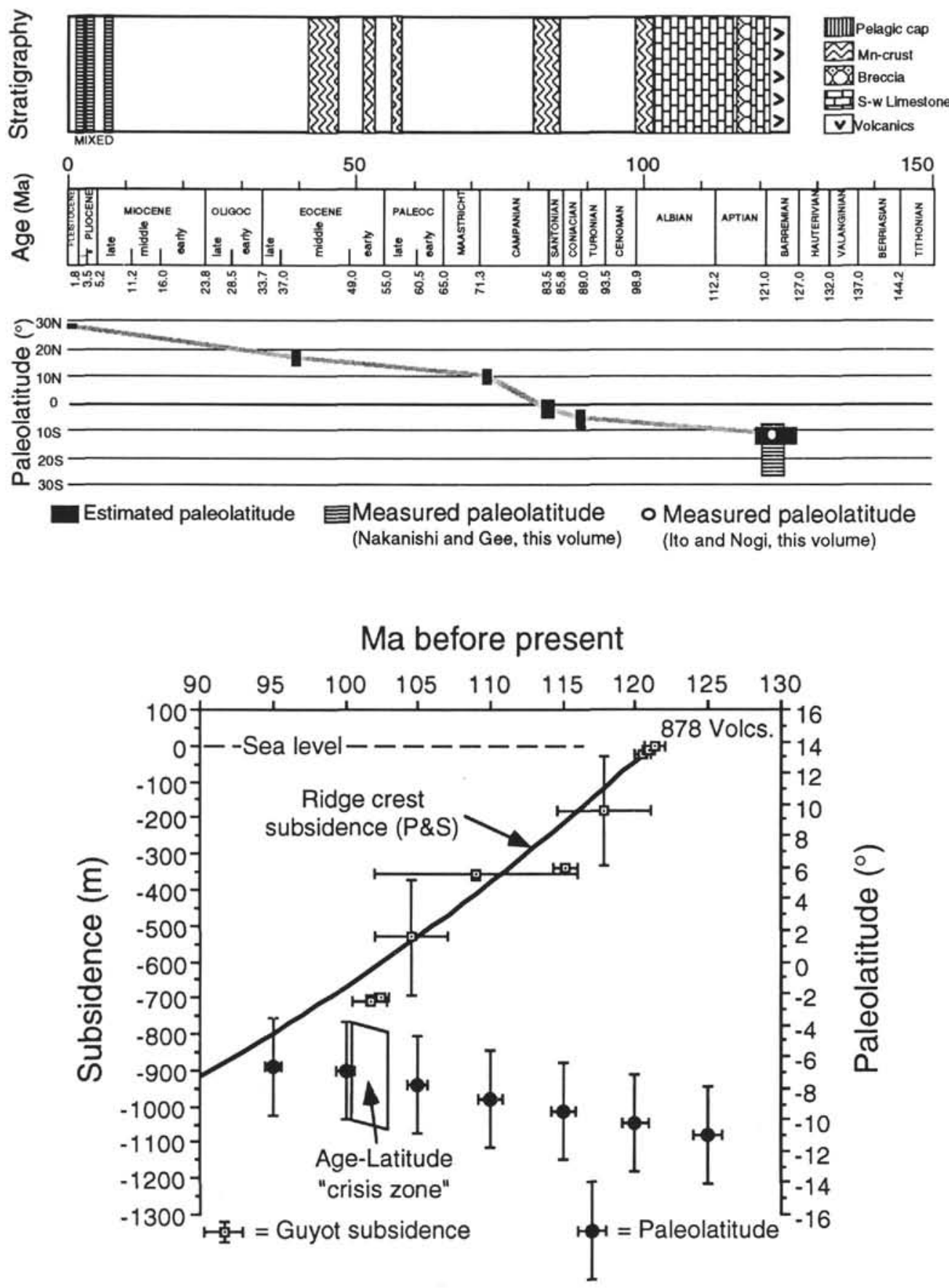

Figure 11. Stratigraphy, subsidence and paleolatitude histories of Site 878 (MIT Guyot). See Figure 8 for complete description.

debris into a deeper site of deposition (Premoli Silva, Haggerty, Rack, et al., 1993; Erba et al., this volume).

Extensive recrystallization and phosphatization of the middle Eocene conglomeratic chalk indicate a prolonged exposure to seawater for up to 15 million years because the deposition of the pelagic cap on Lo-En started only in the late Oligocene. As previously discussed for Limalok Guyot, the accumulation of the pelagic cap was quite discontinuous and periods of nondeposition and/or erosion were documented in the early Miocene, middle Miocene, late Miocene, and early Pliocene (Watkins et al., this volume). Current activity and winnowing waned by the late Pliocene, and the Quaternary sequence seems to be complete (Erba, this volume).

Additional stratigraphic control of the depositional history on LoEn Guyot derives from material dredged along the southern flank of the guyot (Lincoln et al., 1993). Dredge RD33 recovered a breccia of angular fragments of basalts floating in a matrix of shallow-water debris and pelagic carbonates with planktonic foraminifers. The shallowwater debris was dated as Albian and the oldest pelagic sediment was attributed to the latest Albian. Therefore a pre-Albian volcanic episode produced a shallow carbonate bank during the Albian and a more 


\section{Stratigraphy, Subsidence and Paleolatitude}
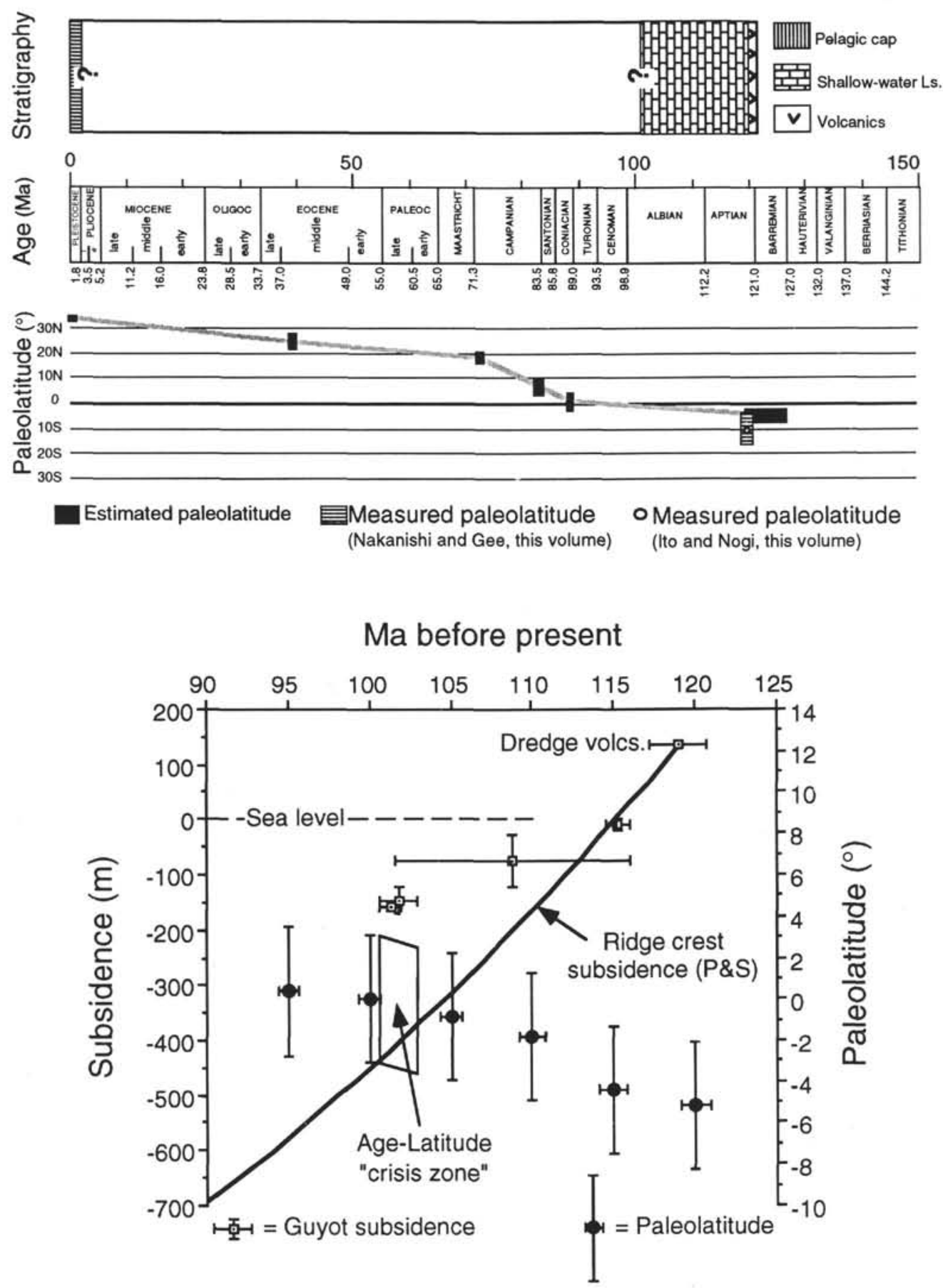

Figure 12. Stratigraphy, subsidence and paleolatitude histories of Sites 879-880 (Takuyo-Daisan Guyot). See Figure 8 for complete description.

pelagic regime was established by latest Albian time. Another breccia from Dredge RD33 consists of basalt pebbles in a matrix bearing planktonic foraminifers of early Campanian age and points to the occurrence of a younger volcanic episode in the area. A manganese-encrusted limestone from the same dredge was attributed to the Coniacian on the basis of planktonic foraminiferal content (Lincoln et al., 1993).

\section{Sites 873-877 (Wodejebato Guyot)}

Five sites were drilled on Wodejebato Guyot, and the stratigraphic synthesis (Fig. 10) results from the correlation of the different se- quences recovered at the various sites. The radiometric dates from four volcanic rock samples (Sites 873,874 , and 876 ) provide a weighted mean age of $83.2 \pm 1.1 \mathrm{Ma}$ (Pringle and Duncan, this volume) that, using the conversion factor, results in the age of $84.4 \pm 1.1 \mathrm{Ma}$ for the volcanic pedestal. Paleomagnetic measurements by Nakanishi and Gee (this volume) and Ito and Nogi (this volume) indicate that the basalts are reversely magnetized and are attributed to Chron $33 \mathrm{R}$. At Sites 873,874 , and 877 , the clayey interval atop the basalts was interpreted as the result of soil development. In particular, the weathering profile at Site $873(22.5 \mathrm{~m})$ exhibits the most extreme alteration and pedogenesis and might have formed in an upland or lowland area. 
The oldest marine sediment consists of black clays that contain wellpreserved calcareous nannofloras indicative of the upper Campanian CC22 Zone (Erba et al., this volume). Cenomanian-restricted nannofossils document the presence on Wodejebato Guyot of older pelagic limestone that were resedimented during the late Campanian. This late Campanian sedimentation occurred under restricted conditions and was followed by the establishment of a Campanian to Maastrichtian carbonate platform. The stratigraphy of the shallow-water sequences recovered at Sites 873 through 877 is primarily based on benthic foraminifers, but the low recovery prevented the precise location of the Campanian/Maastrichtian boundary (Premoli Silva et al., this volume). The biostratigraphic correlation only indicates that the platform sequences at Sites 875 and 876 on the Outer Ridge are younger than the sequences at Site 873 (lagoon) and 874 and 877 (Inner Ridge). Sr-isotope data (Wilson et al. and Wyatt et al., both in this volume) provide constraints to place the Campanian/Maastrichtian boundary. In particular, Maastrichtian values were found down to 140 meters below seafloor (mbsf) at Site 874 and down to 85 mbsf (possibly down to $154 \mathrm{mbsf}$ ) at Site 877 . The Sr-isotope stratigraphy is compatible with the biostratigraphic correlation and provides a better resolution.

The youngest shallow-water carbonates (Sites 875 and 876) are late Maastrichtian in age and only slightly older than the late Maastrichtian drowning of Wodejebato Guyot as documented by planktonic foraminifers in pelagic limestones infilling the top of the platform (Premoli Silva, Haggerty, Rack, et al., 1993; Watkins et al., this volume). Pelagic conditions persisted through the rest of the Tertiary and Quaternary. In the Paleocene and Eocene, various pulses of pelagic limestone sedimentation were recorded in manganese-encrusted hardgrounds as reconstructed by Watkins et al. (this volume) on the basis of calcareous nannofossils and planktonic foraminifers.

The onset of deposition of the pelagic cap was dated as earliest Miocene. It was sporadic throughout the Neogene and Quaternary, with accumulation during the earliest Miocene, part of the middle Miocene, latest Miocene to early Pliocene, and early Pleistocene (Watkins et al. and Erba, both in this volume). Several hiatuses resulted from the intense current activity that winnowed the foraminifer-nannofossil oozes atop the guyot.

Site 869 was drilled during Leg 143 on the archipelagic apron south of Wodejebato Guyot to recover a pelagic sequence (Sager, Winterer, Firth, et al., 1993). The stratigraphy of the Cretaceous sequence is discussed by Erba et al. (this volume). Most of the Upper Cretaceous sequence consists of volcaniclastic breccias and sandstones mixed with pelagic sediments; two major pulses of volcanism were dated as Campanian and Cenomanian, respectively (Sager, Winterer, Firth, et al., 1993). The Campanian volcanic episode is well dated by calcareous nannofossils and planktonic foraminifers as early Campanian. In addition, it is correlative of Chron 33R and, hence, coeval with the basalts drilled on the summit of Wodejebato Guyot. Shallow-water debris was found at various levels in the Campanian at Site 869. The benthic foraminiferal assemblages are very similar to those recovered at the sites drilled on the summit of Wodejebato Guyot.

Four samples from the Cenomanian volcaniclastic breccia at Site 869 were dated by Pringle and Duncan (this volume). The resulting weighted age is $94.4 \pm 0.3 \mathrm{Ma}$, which gives a converted age of $95.7 \pm$ $0.3 \mathrm{Ma}$ for the Cenomanian episode. This age is consistent with the reworked nannofossils found at Site 877 on the Inner Ridge of Wodejebato Guyot (Erba et al., this volume). Shallow-water debris was recovered in the thick volcaniclastic interval at Site 869. Most of the shallow-water material is resedimented at the base of the Cenomanian turbidites, but a few layers were found also in the Turonian and Coniacian. No age-diagnostic forms have been found and, consequently, only a general mid-Cretaceous age is attributable to this debris. Because there is no evidence that the shallow-water organisms are younger than Albian, these findings at Site 869 may represent reworking of fragments of an Albian carbonate platform during the Cenomanian (to Coniacian?) volcanic episode.
Dredges from the southern flank of Wodejebato Guyot recovered material that is discussed by Lincoln et al. (1993). Dredge RD47 contained a breccia with basalts and planktonic foraminifers of late Santonian to early Campanian age. Manganese-encrusted limestones and shallow-water debris were recovered with Dredge RD50. Two generations of shallow-water material were identified. The younger is attributed to the Campanian-Maastrichtian based on benthic foraminifers and the older is dated as Albian based on rudists (Fig. 10). The dredged material suggests that Wodejebato experienced at least two episodes of volcanism and subsequent building of a carbonate platform. While there is evidence for an Albian and a CampanianMaastrichtian platform on Wodejebato, no shallow-water debris of Cenomanian through Campanian age have been recorded in the area.

\section{Site 878 (MIT Guyot)}

Site 878 (Fig. 11) is located just inside the southern perimeter ridge of MIT Guyot and bottomed in $187 \mathrm{~m}$ of volcanics. Radiometric dating of these basalts allowed the identification of three analytically distinct groups of ages (Pringle and Duncan, this volume). The deepest basalt samples averaged $122.8 \pm 0.2 \mathrm{Ma}$, one intermediate-level basanite (Core 144-878A-80R) gave an age of $121.7 \pm 1.6 \mathrm{Ma}$, and three hawaiites, one from the upper lava sequence and two from clasts found near the top of the polymictic breccia, provided an age of 119.6 $\pm 0.7 \mathrm{Ma}$. Converted to the Gradstein et al. (1994) time scale, these ages date the sampled volcanic pedestal from 124.5 to $121.3 \mathrm{Ma}$. The bottom $60 \mathrm{~m}$ of basalts are reversely magnetized (Nakanishi and Gee, this volume; Ito and Nogi, this volume) and were identified as Chron M1R (Erba et al., this volume; Pringle and Duncan, this volume). Atop the volcanics, $9 \mathrm{~m}$ of clays may represent the very deep parts of a soil profile or alteration by groundwaters (Holmes, this volume).

Shallow-water deposition was established during the early Aptian, and this carbonate platform (118.24 $\mathrm{m}$ in thickness) developed in a fully oxygenated environment with one episode of more pelagic influence. In particular, calcareous nannofossils in Core 144-878A-75R constrain the deposition to a short interval within the early Aptian. This older carbonate platform was abruptly interrupted by a volcanic episode in the late early Aptian which resulted in a $303 \mathrm{~m}$ layer of volcaniclastic breccia. This volcanism was followed by deposition of a younger carbonate platform in the late Aptian to Albian. Approximately $352 \mathrm{~m}$ of shallow-water limestones accumulated under restricted to more open marine conditions (Arnaud Vanneau and Premoli Silva, this volume). While benthic foraminifers indicate that the youngest carbonate platform is late Albian in age (Arnaud Vanneau and Premoli Silva, this volume), Sr-isotope stratigraphy suggests a latest Albian age for the top of the platform (Wilson et al., this volume).

Manganese crusts and nodules were found atop the shallow-water platforms and within the pelagic cap on MIT Guyot. The oldest pelagic sediment consists of phosphatized limestones with planktonic foraminifers of latest Albian age and indicates that the drowning of the platform occurred in a short interval before the end of the Albian. The detailed investigation by Watkins et al. (this volume) on the manganese nodules allowed the reconstruction of episodes of pelagic carbonate sedimentation in the Santonian-early Campanian, late Paleocene, early Eocene, and middle Eocene. The pelagic cap on MIT Guyot is restricted to $3 \mathrm{~m}$ of oozes that contain very mixed calcareous nannofloras of latest Miocene to early Pleistocene age (Premoli Silva, Haggerty, Rack et al., 1993; Watkins et al., this volume).

\section{Site 879-880 (Takuyo-Daisan Guyot)}

Site 879 (Fig. 12) was drilled on the eastern margin of TakuyoDaisan Guyot to penetrate the Cretaceous carbonate platform and the underlying basalts, whereas Site 880 was located on the central summit region of the guyot to recover the pelagic cap. Drilling at Site 879 recovered about $20 \mathrm{~m}$ of basalts and breccias. The radiometric ages 
of two samples were unsuitable for dating the basalts at Site 879 and previously dredged material was used for dating the volcanics on Takuyo-Daisan Guyot (Pringle and Duncan, this volume). These dredge samples were dated relative to a different dating standard (FCT-3 biotite at $27.7 \mathrm{Ma}$ ) than the volcanics recovered from Sites 872-878. The reported age (Pringle and Duncan, this volume) on Dredge A5-37-3 from the flank of the guyot is $118.4 \pm 1.8 \mathrm{Ma}$. When multiplied by a conversion factor of 1.0049 , this yields $119.0 \pm 1.8$ Ma on the Gradstein et al. (1994) time scale.

Atop the basalts in the drill hole, a $40.2 \mathrm{~m}$ thick clayey unit may represent the deepest part of a weathering profile or the alteration by groundwater (Holmes, this volume). Carbonate platform deposition resulted in $169.7 \mathrm{~m}$ of shallow-water limestones of late Aptian to Albian age. The initial marine flooding of the volcanic edifice at Takuyo-Daisan Guyot is well constrained by calcareous nannofossils and planktonic foraminifers of late Aptian age found in Cores 144$879 \mathrm{~A}-18 \mathrm{R},-17 \mathrm{R}$, and -16R (Erba et al., this volume). The stratigraphic resolution of the carbonate platform sequence at Site 879 is very poor because of the extremely low recovery. The top of the carbonate platform is attributed to the latest Albian based on benthic foraminifers (Arnaud Vanneau and Premoli Silva, this volume) or to the late Albian based on Sr-isotope stratigraphy (Wilson et al., this volume).

The contact between the shallow-water limestones and the pelagic sediments was not recovered at Sites 879 and 880 and, therefore, the age of drowning remains unknown. Similarly, the onset of sedimentation of the pelagic cap was not determined because only two cores were drilled at Site 880 . Drilling at this site revealed a possibly continuous sedimentation of oozes and ash layers through the Pleistocene and uppermost Pliocene (Erba, this volume).

\section{SUBSIDENCE AND PALEOLATITUDE RESULTS}

\section{Site 871 (Limalok Guyot)}

Because all of the data sets and methods have been cited completely in the previous sections, and to provide a results section that is more compact and easier to read, we adopt the convention of not repeating those citations here. The reader is referred to the previous sections for those citations, many of which are also shown on Figures 8-12.

The sedimentary history of the carbonate platform of each guyot is partitioned into units that each have a particular age range and thickness, as in the example of Limalok Guyot shown in Figure 7. The "carbonate platform units" column (Fig. 7) shows three of these units numbered 1,2 , and 3 . These numbered units are represented on the subsidence diagram in Figure 8 as crossed error bars that represent the age range and thickness of each of these sedimentary units. By assuming that these shallow-water, marine sedimentary sequences accumulated at sea level and have not been subsequently compacted or eroded, we conclude that these units are a record of the observed subsidence history of each guyot. Thus we show these sedimentary units in inverse stratigraphic order on the subsidence plots to represent the sedimentary and subsidence histories of these guyots compared to a model subsidence curve. The age range of the youngest sedimentary unit forms the age range of a parallelogram that we call the Age-Latitude "crisis zone" for this carbonate platform, because this parallelogram should enclose the age and paleolatitude at the death of this shallow-water ecological community. The crisis zones for all guyots studied on Leg 144 are compiled in Figure 13.

The carbonate platform units shown on Figure 7 are bounded below and above by the uppermost, weathered volcanic rocks of Limalok Volcano and a manganese crust, respectively. On all other guyots, the volcanic rocks could be dated with considerable precision. However, on Limalok we must resort to approximating the age of the volcanics with an estimate of how long it took the deeply weathered paleosol to form at the top of the volcanics (Holmes, this volume), in this case, $3 \mathrm{Ma}$. That time is added to the age of the oldest marine sediments and plotted at the top of the subsidence curve in Figure 8. The manganese crust atop Limalok contains planktonic foraminifers

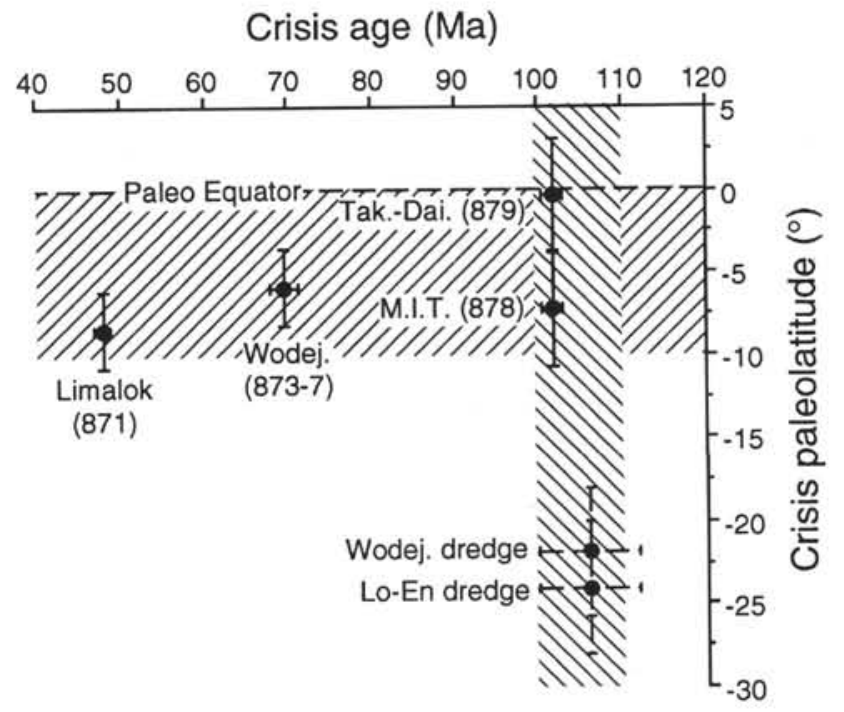

Figure 13. Ages and paleolatitudes of "crisis zones" for Leg 144 guyots. These crisis zones are defined by the ages and paleolatitudes of the youngest carbonate platform sediments on each guyot. They should be coincident in age and paleolatitude with the deaths of the ecological communities that built the carbonate platforms. The data all can be encompassed either within a crisis paleolatitude range of $0^{\circ}-10^{\circ} \mathrm{S}$, suggesting a paleoequatorial cause for the death of some of the carbonate platforms or within a crisis age range of 100-110 $\mathrm{Ma}$, suggesting a cause of death of some of the carbonate platforms in the Albian, probably the late Albian.

and calcareous nannofossils that require the carbonate platform to have been drowned and submerged by $45-47 \mathrm{Ma}$. This serves as a check on the age of the age-latitude "crisis zone." Similar crusts were recovered on all other guyots except Takuyo-Daisan. The age-paleolatitude crisis zone of Limalok is restricted to a very narrow age band $(47-49 \mathrm{Ma})$ and a $5^{\circ}$-wide paleolatitude band centered at about $6^{\circ}$ South. Both of these ranges are well defined.

The "871 Volcs." are plotted $171 \mathrm{~m}$ above sea level on Figure 8, as an estimate of the initial emergence of Limalok Volcano above sea level (Table 2). The Parsons and Sclater (1977) model ridge crest subsidence curve then subsides from that point using a corrected thermal reset age for the underlying lithosphere of $8 \mathrm{Ma}$ (Table 2). At that time of initial subsidence, the lithosphere beneath Limalok had a magnetic lineation age of $91 \mathrm{Ma}$, so this lithosphere had lost $83 \mathrm{Ma}$ of thermal age, probably during the formation of Limalok Volcano. Note that the younger carbonate platform units ( 2 and 3 in Fig. 8) plot above and to the left of the model ridge crest subsidence curve. This indicates that the first $13 \mathrm{Ma}$ of subsidence history of Limalok was slower than ridge crest subsidence of the same thermal age range. That may have resulted from this lithosphere cooling more slowly than in a ridge-crest subsidence model, and also from dynamic support in the underlying mantle. Either or both of these processes could have slowed the lithospheric subsidence rate. These processes may have been interrelated; additional heat having been supplied to the base of the lithosphere, probably by some convective process associated with dynamic uplift in the mantle during the first $13 \mathrm{Ma}$ of Limalok's subsidence history. It is also likely that this was a continuation of the thermodynamic processes responsible for the large initial thermal age loss. McNutt and Fischer (1987) and McNutt and Judge (1990) reached similar conclusions regarding the present-day lithosphere and mantle beneath the Tahiti superswell with an analysis of lithospheric depth and age in that area. Utilization of a fixed hot-spot model would backtrack Limalok Guyot to the Tahiti area at its time of volcanic formation, supporting previous suggestions that the Tahiti superswell is a long-lived mantle upwelling. McNutt and Fischer (1987) considered the Tahiti super- 
swell to be the modern-day equivalent of conditions there in the Cretaceous, while Larson (1991) suggested that the present-day superswell is probably the nearly exhausted remnant of the mid-Cretaceous upwelling, rather than a present-day analogue.

\section{Site 872 (Lo-En Guyot)}

Lo-En has the poorest-known early history of all the guyots studied on Leg 144. A well-defined radiometric age of 114.4 $\pm 1.2 \mathrm{Ma}$ on the guyot volcanics and a shallow-water limestone dredge of Albian material from a previous expedition are the only controls we have on its critical subsidence and paleolatitude histories. An attempt to calculate a thermal reset age for Lo-En, based on the age and depth of the $114 \mathrm{Ma}$ volcanics failed because the age-depth window defined by these values and used in the backtrack method extends well beyond the age of the plate (155 Ma) on the Parsons and Sclater (1977) subsidence curve. This implies that the thermal reset age exceeds the age of the plate, which is impossible. There is no place on the model subsidence curve where such a small amount of subsidence (1226 m) can be fitted in such a large amount of time (114 Ma). Unless an abnormally large unconformity existed at the volcanic/sediment interface, this implies that uplift of the guyot occurred sometime subsequent to the $114 \mathrm{Ma}$ volcanic episode, removing some of the subsidence that had already occurred. This probably occurred in the Campanian, synchronous with the volcanic episode on nearby Wodejebato Guyot, as evidenced by the Campanian volcaniclastic pebble conglomerate at Site 872 discussed by Watkins et al. (this volume).

Given the almost certainty of subsequent volcanism, no subsidence curve can be calculated for the 114-Ma volcanic platform because subsequent uplift would have disturbed that subsidence history in an unknown way. In general, if multiple uplift episodes are recorded on an individual guyot, only the thermal cooling history of the final episode can be modeled. We note as an aside that subsidence after a final thermal event may actually be a record of the integrated cooling history of multiple reheating episodes, although again, it is necessary to treat such a history as a single, terminal thermal event.

Dredge RD33 (Fig. 9) contained shallow-water debris of Albian age and pelagic sediment dated as old as latest Albian. Therefore, it is likely that a shallow-water platform existed atop.Lo-En during most of the Albian and drowned before latest Albian time. This is illustrated in the age-latitude "crisis zone" for Lo-En that extends from 100-112 $\mathrm{Ma}$ and $20^{\circ}-28^{\circ} \mathrm{S}$ paleolatitude. There is little doubt that these limestones originated well south of the equatorial zone in the Albian, because the remanent inclinations measured on the 114-Ma-old volcanics from Site 872 imply an Aptian paleolatitude for Lo-En of $30^{\circ}-31^{\circ} \mathrm{S}$. However, since the dredged material was not recovered "in place," less certainty should be attached to these ranges than to ranges determined from material recovered by drilling. Thus the crisis zone for Lo-En is shown on Figures 9 and 13 as dashed lines.

\section{Sites 873-877 (Wodejebato Guyot)}

Six drill sites from Legs 143 and 144 and two dredges from previous expeditions define the extensive database for Wodejebato Guyot (Fig. 10), which was described in detail in the Stratigraphy section. This database shows direct evidence of two episodes of shallow-water carbonate platform development and subsequent drowning and subsidence. The first episode is based on dredged material from Dredge RD50 where rudists of a nominal Albian age were recovered. Evidence of subsequent drowning is based on a few specimens of Cenomanian calcareous nannofossils at the base of Site 877 atop Wodejebato, and extensive material of the same biostratigraphic and radiometric age from Site 869 on the archipelagic apron. Thus the first age-latitude "crisis zone" for Wodejebato ranges from $100-110 \mathrm{Ma}$ and $19^{\circ}-25^{\circ} \mathrm{S}$ paleolatitude. As with Lo-En Guyot, this crisis zone is plotted as dashed lines on Figures 10 and 13 because it is based on dredged material recovered out of its original stratigraphic sequence. Although this information can be used to define such a crisis zone, it cannot be used to construct a subsidence curve because of a subsequent uplift episode, similar to our inference for the history of Lo-En Guyot. Thus, the basic age-dating information for the Albian and Cenomanian is plotted at sea level on the subsidence diagram in Figure 10 to illustrate our ignorance of its complete subsidence history.

Drilling information from five sites on Leg 144 atop Wodejebato can be used to reconstruct a relatively short, but more precise, subsidence history of Late Cretaceous carbonate platform growth and drowning. The age of volcanics atop the guyot is placed at about 83 $\mathrm{Ma}$, based on a combination of radiometric dating from Sites 873,874 and 876 and the sampling of reversely magnetized material within these volcanics that is indicative of Chron 33R. Remanent magnetic inclination and magnetic logging place the paleolatitude of these volcanics at about $10^{\circ} \mathrm{S}$, in close accord with the polar wander path prediction of about $16^{\circ} \mathrm{S}$. The error limits of these measurements overlap at the $95 \%$ confidence interval.

The corrected thermal reset age for the lithosphere beneath Wodejebato at the end of the last ( $83 \mathrm{Ma}$ ) uplift event is estimated to be 21 $\mathrm{Ma}$, and the initial emergence above sea level of Wodejebato Volcano is estimated to be $236 \mathrm{~m}$. Thus, the dates on the volcanics from Sites 873,874 , and 876 are placed at the top of a subsidence curve beginning $236 \mathrm{~m}$ above sea level, and the subsequent model subsidence is initiated at a thermal reset age of $21 \mathrm{Ma}$. At that time of initial subsidence, the lithosphere beneath Wodejebato had a magnetic lineation age of $\sim 77 \mathrm{Ma}$, so this lithosphere had lost $\sim 56 \mathrm{Ma}$ of thermal age, probably during the formation of Wodejebato Volcano. The short, marine carbonate platform sequence ranges in age from about $76 \mathrm{Ma}$ to $69 \mathrm{Ma}$, and the younger part of this sequence generally plots above and to the left of the ridge crest subsidence curve. This indicates that the first 7 $\mathrm{Ma}$ of subsidence history of Wodejebato was slower than ridge crest subsidence of the same thermal age. It is likely that this slower subsidence rate resulted from the same set of thermodynamic conditions proposed above for the subsidence history of Limalok Guyot.

The second age-latitude "crisis zone" is defined by these youngest sediments to range in age from 68 to $71.3 \mathrm{Ma}$ and corresponds to a paleolatitude range of about $4^{\circ}-8^{\circ} \mathrm{S}$. This crisis age is confirmed by pelagic infilling in uppermost platform carbonate sediments in Site 874 that ranges in age from 67 to $68 \mathrm{Ma}$. Thus, Wodejebato's second platform carbonate sequence must have been drowned and subsiding by $67-68 \mathrm{Ma}$.

\section{Site 878 (MIT Guyot)}

Site 878 was drilled on MIT Guyot and contains the largest carbonate platform stratigraphic record, both in terms of stratigraphic thickness and age, so it presents the best possibility to study the subsidence history of any of the Leg 144 guyots. MIT Guyot is also unique in this data set in that it appears to have originated its subsidence history from sea level, because there is no age gap at the volcanic/sediment interface. Thus, the 121 Ma radiometric date on the Site 878 volcanics is placed at sea level at the top of the subsidence curve in Figure 11. The model ridge crest subsidence curve is generated from that point using an initial thermal age of $19 \mathrm{Ma}$, which is the corrected thermal reset age (Tables 1 and 2) of the underlying lithosphere just after the volcano formed. At that time of initial subsidence, the lithosphere beneath MIT had a magnetic lineation age of $36 \mathrm{Ma}$, so this lithosphere had lost $17 \mathrm{Ma}$ of thermal age, probably during the formation of MIT Volcano.

The stratigraphic ages of the carbonate platform section are controlled by a combination of calcareous nannofossils, planktonic and benthic foraminifers and strontium isotope data. In the interpretation shown in Figure 11, calcareous nannofossils determine the stratigraphy of the oldest part of the section from 121 to $115 \mathrm{Ma}$. For the post-115 Ma portion of the section, a combination of microfossil data is used, and the benthic foraminifers are considered to be especially important indicators of the critical age at the top of the carbonate platform that 
defines the age-latitude "crisis zone." This age is established as 100.5 $103 \mathrm{Ma}$ and is confirmed by planktonic foraminifers in an overlying manganese nodule with an age range of 100.5-101.5 Ma.

Although there are large ranges at certain stratigraphic levels, the observed stratigraphy of the carbonate platform closely follows the model ridge crest subsidence curve, indicating that the thermodynamic conditions beneath MIT Guyot during its initial $19 \mathrm{Ma}$ of subsidence (from 121 to $102 \mathrm{Ma}$ ) were a close approximation of a ridge crest subsidence model with a thermal age range of $19-38 \mathrm{Ma}$. This is in contrast to the subsidence histories of the Limalok and Wodejebato areas in the Marshall Islands, which subsided more slowly than ridge crest subsidence models with corresponding thermal age ranges. Apparently thermodynamic conditions beneath MIT during its subsequent subsidence history were indistinguishable from those in the Parsons and Sclater (1977) ridge crest subsidence model. Thus, it is unnecessary to invoke unusually slow cooling or dynamic uplift beneath the guyot during that time period. This may have resulted from the isolated location of MIT Guyot relative to other centers of midCretaceous volcanism such as the Marshall Islands. The more voluminous volcanism in the Marshall Islands suggests more anomalous conditions in the underlying lithosphere and/or mantle than were present under MIT. It also may be a coincidence that MIT is the only Leg 144 guyot without any significant initial volcanic emergence above sea level, or this may be further evidence for the lack of abnormal conditions in the lithosphere/mantle at this location.

The age-latitude "crisis zone" is bounded by the 100.5-103 Ma age range described above and by a paleolatitude range of about $4^{\circ}-11^{\circ} \mathrm{S}$ (Figs. 11 and 13). Although the estimated and measured paleolatitudes of the Aptian-aged volcanics are all in close agreement, the paleolatitude range of the crisis zone is determined by interpolation between two widely spaced (in time) poles on the Pacific polar wander path (Figs. 6 and 11). While we have no other reason to doubt this paleolatitude range, we point out that it needs independent confirmation by future studies.

\section{Site 879 (Takuyo-Daisan Guyot)}

Site 879 (Fig. 12) was drilled on Takuyo-Daisan Guyot and, with the exception of Lo-En Guyot, it contains the poorest record of subsidence and paleolatitude of the Leg 144 guyots. The volcanics at the base of Site 879 were unsuitable for radiometric dating, but dating was successfully accomplished on rocks dredged from the flank of the guyot. This dredge yielded an age of $119.0 \pm 1.8 \mathrm{Ma}$, which is $4 \mathrm{Ma}$ older than the oldest marine sediments, reliably dated at 114.5-116 Ma by calcareous nannofossils. This $4 \mathrm{Ma}$-age gap implies an initial emergence of the volcano of $138 \mathrm{~m}$ and a corrected thermal reset age for the lithosphere of $22 \mathrm{Ma}$ (Table 2). Thus the $119 \mathrm{Ma}$ age of the dredged volcanics is placed $138 \mathrm{~m}$ above sea level on the subsidence curve, and the model ridge crest subsidence is calculated starting at a thermal reset age of $22 \mathrm{Ma}$. At that time of initial subsidence, the lithosphere beneath Takuyo-Daisan had a magnetic lineation age of $24 \mathrm{Ma}$, so this lithosphere had lost only $2 \mathrm{Ma}$ of thermal age during the formation of Takuyo-Daisan Volcano.

The age of the stratigraphic section is only well controlled at its bottom by calcareous nannofossils and at its top by a combination of planktonic and benthic foraminifers. As at MIT Guyot, the benthic foraminifers are considered critical in dating the top of the formation, which has an identical age range of 100.5-103 Ma as that found at the top of MIT Guyot. Unlike MIT, this age cannot be confirmed by a date on overlying manganese crust because none was recovered by Leg 144.

Although the stratigraphy is not well controlled and the section is physically short, it appears that the observed subsidence of TakuyoDaisan Guyot falls significantly to the left and above the model ridge crest subsidence curve (Fig. 12). As with the Marshall Islands guyots, this indicates that the lithosphere cooled more slowly than in a ridge crest subsidence model with the same thermal age range, and/or that dynamic uplift was present in the mantle beneath Takuyo-Daisan during its initial $18 \mathrm{Ma}$ of subsidence history. Thus, there appears to be an inconsistency between the small amount of thermal age loss to the lithosphere during volcanic construction and the subsequent, slowerthan-normal, subsidence history. Only $2 \mathrm{Ma}$ of lithospheric thermal age was lost during the volcanic construction of this guyot, and yet its subsequent subsidence is clearly slower than predicted for a ridge crest subsidence model with the same thermal age range. Such a small loss of thermal age could be interpreted to imply that the underlying thermodynamic structure was not disturbed during volcanic construction, but the subsequent subsidence history implies just the opposite. In groping for an explanation, we speculate that the volcano might have formed over lithosphere and mantle that was essentially unaltered by this volcanic event. Subsequent Pacific Plate motion then could have drifted Takuyo-Daisan Guyot over a location of anomalous upwelling. This explanation, while possible, is obviously somewhat contrived. Thus, this is the most perplexing result of the thermal reset age/subsidence study.

The caveats that apply to the paleolatitude data on MIT Guyot also apply to Takuyo-Daisan Guyot. Although the estimated and measured paleolatitudes of the Aptian volcanics are generally in accord, the age-latitude "crisis zone" falls in the same late Albian gap on the Pacific Plate polar wander path. With these caveats in mind, the paleolatitude range of the crisis zone for Takuyo-Daisan Guyot is $2^{\circ} \mathrm{N}$ to $3^{\circ} \mathrm{S}$ paleolatitude.

\section{SPECULATIONS ON THE CAUSES OF CARBONATE PLATFORM DEMISE}

In the previous section we have presented the results of stratigraphic and paleolatitude studies that allow us to define a number of age-latitude "crisis zones" that should be coincident with the times and paleolatitudes of death of the carbonate platforms in question. This information is compiled in Figure 13. These crisis zones all can be encompassed either within a crisis paleolatitude range of $0^{\circ}-10^{\circ} \mathrm{S}$, suggesting a paleoequatorial cause for the death of some of the carbonate platforms; or within a crisis age range of 100-110 Ma, suggesting a cause of death of some of the carbonate platforms related to Albian time. This crisis age range probably can be restricted to late Albian time (100-103 Ma), because our best-known Albian crisis zones can all be restricted to that interval. However, the dredged material from Lo-En and Wodejebato Guyots have poorly defined Albian ages, and it was not recovered from "in place" locations in the stratigraphic sections. Thus we have chosen a conservative approach in this interpretation, keeping in mind that a more precise crisis age range probably will be possible in future studies. In the remaining sections we speculate on the possible causes of death of these carbonate platform communities in late Albian time and/or at equatorial paleolatitudes.

\section{Late Albian Crisis}

The synchronous drownings of shallow-water platform in the Pacific Ocean is striking if the records of MIT and Takuyo-Daisan Guyots (Fig. 13) are compared with the dredged material from Lo-En and Wodejebato Guyots (Lincoln et al., 1993) and with Leg 143 drilling results at Site 865 (Allison Guyot) and Site 866 (Resolution Guyot) (Sager, Winterer, Firth et al., 1993; Sliter, 1995). At Lo-En, a preAlbian volcanic episode produced an Albian carbonate platform that was drowned in latest Albian time. Similarly, dredged material from Wodejebato documents the existence of an Albian platform followed by Cenomanian to Santonian pelagic facies. As pointed out by Sliter (1995), at both Allison and Resolution Guyots shallow-water limestones younger than Albian have not been recovered and therefore the demise of these carbonate platforms (Grötsch and Flügel, 1992) and the coeval hiatuses occurred in the latest Albian. Grötsch and Flügel (1992) describe the simultaneous demise of carbonate platforms in the northwestern Pacific guyots during the latest Albian. 
These six mid-Cretaceous atolls were spread over a broad area, and at the time of their demise they were located between $0^{\circ}$ and $25^{\circ} \mathrm{S}$ paleolatitude (Fig. 13). Hence, a time-related event, as opposed to a geographic cause may explain the drowning of the Aptian-Albian carbonate platforms. As discussed by Sliter (1995), the uppermost Albian of the Pacific Ocean records changes in the sedimentary regime at shallow and deeper sites. In pelagic sequences, a hiatus is usually recorded in the Cenomanian after the deposition of latest Albian limestones. The transition from limestone to chalk in the uppermost Albian section at Site 463 was interpreted by Sliter (1995) as the result of a lowered sedimentation rate during a sea level drop followed by a rapid rise in sea level. Late Albian short-term fluctuations in relative sea level were also proposed to explain the latest Albian demise of carbonate platforms and the coeval hiatuses recorded in pelagic sequences (Sliter, 1995). Although the role of sea level fluctuations in the late Albian cannot be disregarded, we note that Haq et al.'s (1987) eustatic sea level curve does not show major changes in the late Albian. Furthermore, preliminary stable isotopic results from MIT and Takuyo-Daisan Guyots show little evidence to substantiate pervasive alteration of limestones by meteoric water that would have resulted from the supposed subaerial emergence of those carbonate platforms during a late Albian low stand in sea level. Other paleoceanographic events must be considered to explain the history of the mid-Cretaceous oceans. Quantitative investigation of calcareous nannofloras at several pelagic sites in the western Pacific Ocean (Roth, 1981; Erba, 1992) pointed out that the changes in assemblages and consequently in the lithology (including the limestone/chalk transition at Site 463) seem to be strictly related to the position of the sites relative to the paleoequator. However, although biotic and lithologic changes occurred at most sites in the late Albian to earliest Cenomanian, these events are not synchronous, and it is possible to reconstruct time progressive changes related to the paleolatitude of sites and the Pacific Plate motion toward the paleoequator.

Changes in upper Albian shallow-water and pelagic sequences beyond the Pacific Ocean (Sliter, 1995) point to a global change in the paleoceanographic regime. Drowning or truncation of several carbonate platforms in the Tethys and Atlantic Ocean support the interpretation of a time-dependent cause for the crisis of the mid-Cretaceous platforms. In pelagic sequences, it must be noted that the widespread deposition of Barremian to Albian black shales ceased in the latest Albian indicating the onset of a different paleoceanographic regime. A plausible explanation is a cooling resulting in more vigorous circulation and deposition of more-oxygenated sediments during the Cenomanian. The evolutionary patterns of calcareous plankton also show major changes in diversification in the Albian. However, calcareous nannoplankton experienced a speciation episode starting in the middle Albian, certainly before the latest Albian cessation of black shale deposition. Planktonic foraminifers also display a major increase in diversification in the late Albian; the beginning of this diversification pulse is younger than the nannoplankton speciation and slightly older than the latest Albian lithologic change. These modifications in the planktonic community structures may indicate modification in the water masses, thermocline, and/or nutrient availability, but a coherent model explaining this global change in the oceans is premature.

\section{Paleoequatorial Crisis}

This synthesis of guyot subsidence and paleolatitudes may shed some light on the mechanism of carbonate platform drowning for west Pacific guyots. Possible mechanisms for drowning a carbonate platform include the following. (1) A relative drop in sea level, either eustatic in origin or related to uplift of the platform, followed by a rapid relative sea level rise has been considered as a drowning mechanism (e.g., Schlager, 1981). (2) Cooling of surface waters could be responsible for carbonate platform drowning if carbonate production slows to the point where it cannot keep up with subsidence or sea level rise.
Two cooling mechanisms are considered here: either plate motions carried the carbonate platforms into latitudes that could not support high rates of carbonate production (e.g., Winterer and Metzler, 1984) or paleoceanographic conditions cooled regional sea surface waters sufficiently for drowning (e.g., Camoin et al., 1993). (3) Increased nutrient flux also has been proposed as a cause of reduction in carbonate production by hermatypic carbonate platform dwellers, such as many of the corals (Hallock and Schlager, 1986). We will consider each of these proposed drowning mechanisms in light of the subsidence, paleolatitude and drowning histories of guyots drilled during Leg 144 . We will also address a long standing paradox: the proximity of carbonate platform-capped guyots adjacent to living atolls in the Marshall Islands. The question raised by this paradox is why does carbonate production cease atop one volcanic edifice while production apparently continues or is initiated on an adjacent edifice?

\section{Sea-level Change}

Schlager (1981) discussed the possibility of drowning a carbonate platform during a rapid sea level rise followed by exposure during a sea level fall. A similar mechanism was proposed by Grötsch and Flügel (1992) who ascribe the carbonate platform demise of northwestern Pacific guyots to a eustatic regressive-transgressive cycle with an amplitude of about $180 \mathrm{~m}$ in the latest Albian. Winterer et al. (1993) suggested that relative sea level change caused by either eustatic fall or thermal/dynamic uplift may have resulted in the demise of carbonate platforms atop guyots in the Mid-Pacific Mountains. The ages of the age-latitude crisis zones defined earlier in this paper vary widely, so we cannot attribute the demise of all of these platforms to a single, temporal event. However, sea level fluctuations are common throughout the geologic record so this does not rule out the possibility that each guyot drowned during a different sea level fluctuation. Furthermore, if all guyots were uplifted by some mechanism following initial formation, such as passing over a thermal or dynamic swell (e.g., McNutt et al., 1990) the times of exposure and carbonate platform demise would vary since the times of island formation and uplift would vary. This mechanism of killing a carbonate platform should leave distinctive diagenetic and morphologic features related to karstification during subaerial exposure of the limestone. Morphologic evidence of karst formation on some guyots in the Pacific have been presented by several authors (e.g., Van Wassbergen and Winterer, 1993). Possible erosion features on Wodejebato Guyot, like the trough separating the inner and outer perimeter ridges of this guyot, may be difficult to explain without invoking some form of subaerial exposure (e.g., Camoin et al. and Enos et al., both in this volume). However, evidence of wholesale dissolution and precipitation of abundant fresh water cements is notably lacking at all sites drilled during Leg 144. Isotopic evidence of fresh water diagenesis is reported from Site 873 at Wodejebato Guyot (Lincoln et al., this volume) but there is no evidence that would link these cements to a terminal exposure event. Even if these guyots were exposed during one or more sea evel falls, this alone does not require that they cease production. When sea level rises again, why should they not simply resume carbonate production unless there is some other factor involved? Schlager (1981) notes that a healthy carbonate platform community should be able to keep up with just about any reasonable rate of sea level rise.

\section{Temperature Change}

Two mechanisms for temperature change are considered here. One is that plate motions carried the carbonate platforms to latitudes that could not support sufficient carbonate production to keep up with subsidence or sea level rise. Winterer and Metzler (1984) suggested this mechanism as a possible cause for the demise of carbonate platforms in the Mid-Pacific Mountains. The paleolatitude data presented here do not support such a mechanism; just the opposite is the case. The guyots drilled during Leg 144 were formed at low latitudes 
south of the equator and were moving toward warmer, lower latitudes (not toward cooler, higher latitudes) before drowning.

The demise of Albian carbonate platforms on northwestern Pacific guyots was interpreted as the possible result of a short-term cooling event in the latest Albian, synchronous with a regressive-transgressive cycle (Grötsch and Flügel, 1992). Camoin et al. (this volume) suggest that drowning of the platform at Wodejebato could possibly coincide with a brief Late Maastrichtian cooling event that may be related to a transition from equatorial to polar-dominated thermohaline circulation. This cooling event may have produced rapid sea level fluctuations. Sea level fluctuations combined with slower carbonate production rates could possibly have resulted in drowning of the carbonate platform at Wodejebato Guyot. However, two of the other guyots discussed in this paper drowned at different times, MIT during the late Albian and Limalok during the Eocene. Although sea level fluctuations during Albian and Eocene times may coincide with the times of drowning at MIT and Limalok Guyots, respectively, we cannot couple these sea level fluctuations with cooling events similar to the one suggested by Camoin et al. (1993) for the Late Maastrichtian. Even if we could pinpoint a short-term cooling event that might coincide with the demise of the carbonate platform on Limalok Guyot, we could not then explain the fact that while carbonate production ceased on Limalok, it was just beginning on atolls to the north, such as Anewetak (Cole, 1957; Schlanger, 1963).

\section{Nutrient Levels}

Hallock and Schlager (1986) postulated that nutrient availability may control the balance between carbonate production and bioerosion on carbonate platforms. This balance between carbonate production and bioerosion may then determine the rate of carbonate sediment accumulation on a platform. Hermatypic corals generally require warm, clear waters to thrive. Hallock and Schlager (1986) noted that hermatypic corals also thrive in some of the most nutrient deficient waters of the subtropical and tropical seas. They suggest that high plankton densities in nutrient rich waters reduce water transparency, thereby reducing the efficiency of the photosynthetic zooxanthellae. Higher plankton abundance does provide more food for suspension and filter feeders, however, Hallock and Schlager (1986) point out that overfeeding of zooxanthellate corals can cause excess mucus production which then fosters bacterial blooms in the mucus, thereby killing the coral. They also point out that fast-growing, non-hermatypic organisms more effectively utilize abundant nutrients, thereby suppressing coral recruitment when nutrient levels are high. Hallock (1988) points out that nutrient excess also increases bioerosion rates. Populations of bio-eroders thrive in nutrient-rich waters. Even if the framework builders survive nutrient enrichment, the framework will be broken down into sand and mud-sized grains, which then may be more susceptible to physical and chemical erosion. Therefore, carbonate platforms where framework builders dominate (low-nutrient levels) may be able to better keep up with fluctuations in sea level than one where bioerosion reduces the framework to sediments.

Hallock (1988) presented several facies models that are dependent on nutrient levels. Carbonate platform framework and skeletal sands should dominate, and mud production should be limited in nutrient poor waters. Therefore, grainstones and framestones should dominate in high energy, low nutrient environments while packstones and rudstones will dominate in low energy, low nutrient environments. As nutrient levels increase, the abundance of framestones decreases while mud-rich facies (mudstones and wackestones) become more abundant. The present-day Marshall Islands are low-nutrient environments. Deep drilling on Anewetak and Pikinni Atolls showed an overwhelming predominance of carbonate platform limestone and skeletal sands compared with only limited calcareous muds. Drilling on Wodejebato Guyot during Leg 144 yielded abundant skeletal sands at Sites 875 and 876 on the outer perimeter ridge (Enos et al., this volume), carbonate platform limestone and skeletal sands with only a few muddy horizons at Sites 874 and 877 on the inner perimeter ridge (Camoin et al., this volume) and packstones/grainstones alternating with mudstone/ wackestone as well as some intervals rich in skeletal sands at Site 873 in the lagoon (Lincoln et al., this volume). Based on the Hallock (1988) models, these results suggest that nutrient levels in the Marshall Islands were also low during that portion of the Late Cretaceous when limestones were accumulating on Wodejebato Guyot.

At three of the guyots in this study, there is some evidence of an increase in the abundance of calcareous algae and bindstone at the top of the carbonate platforms. For example, the platform carbonates on Wodejebato Guyot are capped by a stromatoporoid-algal-coral bindstone facies (Camoin et al., Premoli Silva et al., Nicora et al., Ogg et al., all in this volume). Rhodoliths, rare throughout most of the lagoonal Site 873 , are present in a few of the cores from the top of the platform unit (Lincoln et al., this volume). Algal deposits are also abundant at the top of Site 871 on Limalok Guyot (Ogg et al., this volume). Increased occurrence of bindstone and calcareous algae is characteristic of Hallock's (1988) mesotrophic to slightly eutrophic facies models. These algal-rich facies on the guyots drilled during ODP Leg 144 may be an indication that the guyots have moved from nutrient poor (oligotrophic) conditions to nutrient-enriched conditions.

The uppermost carbonate platform facies recovered at all guyots in this study consists of packstones and rudstones that have been phosphatized, bored and encrusted with ferromanganese oxides. This facies typically separates drowned, shallow-water, carbonate platform deposits from overlying deep-water deposits (Schlager, 1981). Hallock (1988) suggests that this facies is consistent with excess nutrient levels. She notes that high nutrient levels promote the growth of algal-bacterial mats that may aid in the formation of hardgrounds. Abundance of organic matter that results from the high nutrient supply may reduce oxygen levels sufficiently for formation of authigenic minerals in and on the hardground.

The increase in temperature that would have taken place as these guyots approached the equator could also have played a role in the demise of their carbonate platforms. In present Pacific reefs, El Niño warming events produce coral bleaching, or the inability of the corals to retain zooxanthellae in their tissues. This has resulted in widespread destruction of modern reefs (e.g., Galapagos Islands during the 1982$83 \mathrm{El}$ Niño). By analogy, warming during the approach to the equator may have contributed to the demise of the platform community.

The age-latitude crisis zones determined earlier in this paper mainly occur at low southern latitudes $\left(0^{\circ}-10^{\circ} \mathrm{S}\right)$ that coincide with the paleoequatorial upwelling zone. We suggest that as these guyots entered this zone of higher nutrient availability and productivity, water transparency decreased and the growth rates of algal-symbiont-bearing organisms such as rudist bivalves, corals and larger foraminifers decreased. As nutrient availability increased, population of bio-eroders increased and net carbonate accumulation dropped. Either the reduced rate of carbonate production could not keep up with subsidence of the guyots, or subsidence plus a eustatic rise may have outpaced the lower rate of accumulation, leading to the final drowning of the guyots.

This mechanism of drowning may explain how Limalok Guyot could drown while Anewetak Atoll to the north was just starting to accumulate carbonate sediments. While Limalok Guyot was drowning at $6^{\circ}-11^{\circ} \mathrm{S}$ latitude in middle Eocene time, Anewetak was located approximately $5^{\circ}-6^{\circ}$ further north, and may have been north of the high nutrient zone, permitting the carbonate producers to thrive in a more nutrient-poor environment. The atoll-guyot pairs in the Marshall Islands may be explained in a similar fashion. While Wodejebato was drowning at $4^{\circ}-8^{\circ} \mathrm{S}$ latitude in Maastrichtian time, its neighbor Pikinni either had not formed yet or was an emergent volcanic island. (The basalt beneath Pikinni has never been sampled.) If Pikinni then subsided (or formed) when the underlying plate caused it to move northwest out of the crisis zone, a living atoll would then accumulate adjacent to a guyot capped by a failed carbonate platform. 


\section{CONCLUSIONS}

Reheating associated with the initial formation of these volcanos reset the thermal age of the underlying lithosphere to relatively young values, ranging from 8 to $22 \mathrm{Ma}$.

Three out of four volcanos rose significantly above sea level during their volcanic construction phases. Initial summit heights ranged from 138 to $236 \mathrm{~m}$ for these volcanos. Only MIT Volcano had no appreciable initial emergence above sea level.

The same three volcanos that had significant initial emergence above sea level also subsided significantly more slowly than lithosphere generated at spreading ridges of the same thermal age. This indicates that additional heat was supplied to the lithosphere and/or perhaps dynamic uplift was present within the mantle beneath these guyots during their initial subsidence histories. Only MIT Guyot had a subsidence history that closely matched a model ridge crest subsidence curve.

The lithosphere under three of the four guyots lost a significant amount of thermal age (17-83 Ma) during volcanic construction of the guyots. However, the lithosphere under Takuyo-Daisan Guyot was essentially unaffected ( 2 Ma thermal age loss).

The small thermal age loss to the lithosphere beneath TakuyoDaisan Guyot during volcanic construction seems incompatible with its subsequent subsidence history, which is slower than model ridge crest subsidence of the same thermal age range. The first observation implies that the underlying thermodynamic structure was unaffected during volcanic construction, but the second observation implies subsequently anomalous thermodynamic conditions. Perhaps the volcano formed over lithosphere and mantle that was unaltered by that volcanic event, and then drifted over an anomalous upwelling during the subsequent period of subsidence. While possible, this explanation appears somewhat contrived.

The ages and paleolatitudes of the youngest platform carbonate sediments define age-latitude "crisis zones" coincident in time and paleolatitude with the demise of these carbonate platforms.

All of the crisis zone data can be encompassed within either a paleolatitude crisis zone of $0^{\circ}-10^{\circ} \mathrm{S}$ paleolatitude, or within an age crisis zone of $100-110 \mathrm{Ma}$, which potentially can be restricted to 100-103 Ma.

The age crisis zone suggests that a paleoceanographic event in the late Albian caused the drowning of some of these guyots. Such an event might include modification of water masses, thermocline structure, nutrient availability, and/or global warming.

The paleolatitude crisis zone coincides with the paleoequatorial upwelling belt of high productivity. Increases in water opacity and nutrient availability may have caused carbonate accumulation rates to decrease in this situation, and the final drowning may have resulted from these causes augmented by guyot subsidence and possibly eustatic sea level rise.

\section{ACKNOWLEDGMENTS}

We thank M.K. McNutt, R.A. Duncan, and P. Hallock for their careful and useful reviews of our manuscript, and the Leg 144 Scientific Party for their support and help with this work. The senior author thanks R.T. Bird for computational assistance, The U.S. Science Support Program for the Ocean Drilling Program for post-cruise support, and Y. Bogdanov for his shipboard encouragement of this study.

\section{REFERENCES}

Camoin, G., Bellion, Y.J.C., Dercourt, J., Guiraud, R., Lucas, J., Poisson, A., Ricou, L.E., and Vrielynck, B., 1993. Late Maastrichtian (69.5-65 Ma).

\footnotetext{
- Abbreviations for names of organizations and publications in ODP reference lists follow the style given in Chemical Abstracts Service Source Index (published by American Chemical Society).
}

Explanatory notes. In Dercourt, J., Ricou, L.E., and Vrielynck, B. (Eds.), Atlas of Tethys Paleonvironmental Maps: Paris (Gauthier Villars), 179-196.

Cande, S.C., and Kent, D.V., 1992. A new geomagnetic polarity time scale for the Late Cretaceous and Cenozoic. J. Geophys. Res., 97:13917-13951.

1995. Revised calibration of the geomagnetic polarity time scale for the late Cretaceous and Cenozoic. J. Geophys. Res., 100:6093-6095.

Cole, W.S., 1957. Larger foraminifera from the Eniwetok atoll drill holes. Geol. Surv. Prof. Pap. U.S., 260-V:743-784.

Darwin, C., 1837. On certain areas of elevation and subsidence in the Pacific and Indian Oceans, as deduced from the study of coral formations. Proc. Geol. Soc. London, 2:552-554.

Duncan, R.A., and Hargraves, R.B., 1984. Plate tectonic evolution of the Caribbean region in the mantle reference frame. In Bonini, W.E., et al. (Eds.), The Caribbean-South American Plate Boundary and Regional Tectonics. Mem.-Geol. Soc. Am., 162:81-93.

Erba, E., 1992. Middle Cretaceous calcareous nannofossils from the western Pacific (Leg 129): evidence for paleoequatorial crossings. In Larson, R.L., Lancelot, Y., et al., Proc. ODP. Sci. Results, 129: College Station, TX (Ocean Drilling Program), 189-201.

Gradstein, F.M., Agterberg, F.P., Ogg, J.G., Hardenbol, J., van Veen, P., Thierry, J., and Huang, Z., 1994. A Mesozoic time scale. J. Geophys. Res., 99:24051-24074.

Grigg, R.W., and Epp, D., 1989. Critical depth for the survival of coral islands: effects on the Hawaiian Archipelago. Science, 243:638-641.

Grötsch, J., and Flügel, E., 1992. Facies of sunken Early Cretaceous atoll reefs and their capping late Albian drowning succession (northwestern Pacific). Facies, 27:153-174.

Hallock, P., 1988. The role of nutrient availability in bioerosion: consequences to carbonate buildups. Palaeogeogr., Palaeoclimatol., Palaeoecol., 63:275-291.

Hallock, P., and Schlager, W., 1986. Nutrient excess and the demise of coral reefs and carbonate platforms. Palaios, 1:389-398.

Hamilton, E.L., 1956. Sunken islands of the Mid-Pacific Mountains. Mem.Geol. Soc. Am., 64.

Haq, B.U., Hardenbol, J., and Vail, P.R., 1987. Chronology of fluctuating sea levels since the Triassic. Science, 235:1156-1167.

Harland, W.B., Armstrong, R.L., Cox, A.V., Craig, L.E., Smith, A.G., and Smith, D.G., 1990. A Geologic Time Scale 1989: Cambridge (Cambridge Univ. Press).

Hess, H.H., 1946. Drowned ancient islands of the Pacific basin. Am. J. Sci., 244:772-791.

Lancelot, Y., and Larson, R.L., 1975. Sedimentary and tectonic evolution of the northwestern Pacific. In Larson, R.L., Moberly, R., et al., Init. Repts. DSDP, 32: Washington (U.S. Govt. Printing Office), 925-939.

Larson, R.L., 1991. Latest pulse of Earth: evidence for a mid-Cretaceous superplume. Geology, 19:547-550.

Larson, R.L., and Sager, W.W., 1992. Skewness of magnetic anomalies M0 to M29 in the northwestern Pacific. In Larson, R.L., Lancelot, Y., et al., Proc. ODP, Sci. Results, 129: College Station, TX (Ocean Drilling Program), $471-481$.

Larson, R.L., Steiner, M.B., Erba, E., and Lancelot, Y., 1992. Paleolatitudes and tectonic reconstructions of the oldest portion of the Pacific Plate: a comparative study. In Larson, R.L., Lancelot, Y., et al., Proc. ODP, Sci. Results, 129: College Station, TX (Ocean Drilling Program), 615-631.

Lincoln, J.M., Pringle, M.S., and Premoli-Silva, I., 1993. Early and Late Cretaceous volcanism and reef-building in the Marshall Islands. In Pringle, M.S., Sager, W.W., Sliter, W.V., and Stein, S. (Eds.), The Mesozoic Pacific: Geology, Tectonics, and Volcanism. Geophys. Monogr., Am. Geophys. Union, 77:279-305.

McNutt, M.K., and Fischer, K.M., 1987. The South Pacific superswell. In Keating, B.H., Fryer, P., Batiza, R., and Boehlert, G.W. (Eds.), Seamounts, Islands, and Atolls. Geophys. Monogr., Am. Geophys. Union, 43:25-34.

McNutt, M.K., and Judge, A.V., 1990. The Superswell and mantle dynamics beneath the South Pacific. Science, 248:969-975.

McNutt, M.K., Winterer, E.L., Sager, W.W., Natland, J.H., and Ito, G., 1990. The Darwin Rise: a Cretaceous superswell? Geophys. Res. Lett., 17:11011104.

Menard, H.W., 1964. Marine Geology of the Pacific: New York (McGrawHill).

Nakanishi, M., Tamaki, K., and Kobayashi, K., 1992a. Magnetic anomaly lineations from Late Jurassic to Early Cretaceous in the west-central Pacific Ocean. Geophys. J. Int., 109:701-719. 
Nakanishi, M., Tamaki, K., and Kobayashi, K., 1992b. A new Mesozoic isochron chart of the northwestern Pacific Ocean: paleomagnetic and tectonic implications. Geophys. Res. Lett., 19:693-696.

Obradovich, J.D., 1993. A Cretaceous time scale. In Caldwell, W.G.E., and Kauffman, E.G. (Eds.), Evolution of the Western Interior Basin. Spec. Pap. Geol. Assoc. Can., 39:379-396.

Parsons, B., and Sclater, J.G., 1977. An analysis of the variation of ocean floor bathymetry and heat flow with age. J. Geophys. Res., 82:803-829.

Premoli Silva, I., Haggerty, J., Rack, F., et al., 1993. Proc. ODP, Init. Repts., 144: College Station, TX (Ocean Drilling Program).

Roth, P.H., 1981. Mid-Cretaceous calcareous nannoplankton from the central Pacific: implication for paleoceanography. In Thiede, J., Vallier, T.L., et al., Init. Repts. DSDP, 62: Washington (U.S. Govt. Printing Office), 471-489.

Sager, W.W., and Pringle, M.S., 1988. Mid-Cretaceous to Early Tertiary apparent polar wander path of the Pacific Plate. J. Geophys. Res., 93:11753-11771.

Sager, W.W., Winterer, E.L., Firth, J.V., et al., 1993. Proc. ODP, Init. Repts., 143: College Station, TX (Ocean Drilling Program).

Schlager, W., 1981. The paradox of drowned reefs and carbonate platforms. Geol. Soc. Am. Bull., 92:197-211.

Schlanger, S.O., 1963. Subsurface geology of Eniwetak Atoll. Geol. Surv. Prof. Pap. U.S., 260-BB:991-1066.

Schlanger, S.O., Jenkyns, H.C., and Premoli-Silva, I., 1981. Volcanism and vertical tectonics in the Pacific Basin related to global Cretaceous transgressions. Earth Planet. Sci. Lett., 52:435-449.
Sliter, W.V., 1995. Cretaceous planktonic foraminifers from Sites 865,866 , and 869: a synthesis of Cretaceous pelagic sedimentation in the central Pacific Basin. In Winterer, E.L., Sager, W.W., Firth, J.V., and Sinton, J.M. (Eds.), Proc. ODP, Sci. Results, 143: College Station, TX (Ocean Drilling Program), 17-32.

Stein, C.A., and Stein, S., 1992. A model for the global variation in oceanic depth and heat flow with lithospheric age. Nature, 359:123-129.

van Waasbergen, R.J., and Winterer, E.L., 1993. Summit geomorphology of Western Pacific guyots. In Pringle, M.S., Sager, W.W., Sliter, W.V., and Stein, S. (Eds.), The Mesozoic Pacific: Geology, Tectonics, and Volcanism. Geophys. Monogr., Am. Geophys. Union, 77:335-366.

Winterer, E.L., and Metzler, C.V., 1984. Origin and subsidence of guyots in Mid-Pacific Mountains. J. Geophys. Res., 89:9969-9979.

Winterer, E.L., Natland, J.H., van Waasbergen, R.J., Duncan, R.A., McNutt, M.K., Wolfe, C.J., Premoli Silva, I., Sager, W.W., and Sliter, W.V., 1993. Cretaceous guyots in the Northwest Pacific: an overview of their geology and geophysics. In Pringle, M.S., Sager, W.W., Sliter, W.V., and Stein, S. (Eds.), The Mesozoic Pacific: Geology, Tectonics, and Volcanism. Geophys. Monogr., Am. Geophys. Union, 77:307-334.

Date of initial receipt: 2 August 1994

Date of acceptance: 2 December 1994

Ms 144SR-063 